\title{
Om fornying av demonstrativer i norsk
}

\author{
Av Urd Vindenes
}

Formålet med studien som presenteres i denne artikkelen, er å kartlegge bruksområdene og funksjonene til norske demonstrativkonstruksjoner som er bygd opp av et "grunndemonstrativ", f.eks. den, denne, hun og han, og en forsterker, f.eks. her eller derre. Videre er målet å drøfte utviklinga av disse demonstrativene i lys av modeller om forsterkingssykluser og paradigmatisk konkurranse. Datagrunnlaget for analysen er hovedsakelig autentiske talte ytringer fra Nordisk dialektkorpus, samt skriftlige historiske dokumenter fra bl.a. Diplomatarium Norvegicum. Det argumenteres for at de nydanna komplekse demonstrativene i norsk har spesialiserte pragmatiske funksjoner, henholdsvis eksoforisk deiksis og bakgrunns-deiktisk funksjon. Syklisk forsterking av demonstrativer har fellestrekk med forsterking av nektingsuttrykk, og den paradigmatiske konkurransen som oppstår ved forsterking, kan føre til katalysering av grammatikaliseringa av gamle demonstrativer/ nektingsuttrykk. I motsetning til hva som noen ganger har vært hevda i litteraturen om demonstrativer, er grammatikalisering dermed et resultat av snarere enn årsak til forsterking.

\section{Introduksjon*}

I norsk kan vi bruke både enkle og komplekse demonstrativer, som i den boka vs. den der boka. Denne artikkelen presenterer en korpusbasert unders $\varnothing$ kelse av de ulike demonstrativene i talespråk, og den analyserer også utviklinga av komplekse demonstrativer som del av såkalte forsterkingssykluser.

* Tusen takk til de to anonyme konsulentene og til redaktør Hans-Olav Enger for konstruktive kommentarer som har forbedra artikkelen betydelig. Innholdet i deler av artikkelen (avsnitt 4, 5.1, 5.4 og 6) baserer seg på data og analyser som er lagt fram i en upublisert doktorgradsavhandling (Vindenes 2018a: 71-142 og 169-172). Analysene $\mathrm{i}$ avsnitt 5.2 og 5.3, og til dels 4.5, baserer seg på nyinnsamla data. I avsnitt 6 avviker den teoretiske argumentasjonen noe fra den som er lagt fram i avhandlinga. 


\section{URD VINDENES}

Demonstrativer har en sentral og grunnleggende funksjon i språket, og regnes som en universell kategori (Diessel 1999: 154, Dixon 2003: 61). I tillegg til at de brukes til å rette oppmerksomheten til samtalepartneren mot konkrete ting i de fysiske omgivelsene (Sepå den der!), har de også en rekke diskursinterne funksjoner, for eksempel anaforisk referanse eller (re)aktivering av ikke-saliente referenter. Demonstrativer er dessuten frekvente, og de brukes tidlig i barnespråk sjøl om den kontrastive funksjonen kanskje ikke er på plass før seinere (Diessel 2006: 465, Clark 2009: 145). Likevel blir demonstrativer ofte ikke behandla som en sjølstendig kategori i grammatiske og språkhistoriske standardverk, og de har heller ikke vært utforska så grundig som grammatiske elementer som personlige pronomen eller preposisjoner. Noe av grunnen til dette kan være at demonstrativer faller mellom to stoler: De utgjør en lukka klasse, men er ikke like grammatiske som personlige pronomen eller artikler, og de er heller ikke så leksikalske som preposisjoner. Dessuten kan demonstrativer ha ulike syntaktiske funksjoner, og være pronomen, determinativ eller adverb - og dermed bli strukket over flere ordklasser. I denne artikkelen vil ord som her(re), der(re) og andre varianter som kan stå til et demonstrativ, bli kalt for demonstrativforsterkere, ettersom det er fellesnevneren for funksjonen deres, og de regnes som en del av et komplekst demonstrativ, det vil si et deiktisk ord som er forsterka med et tillegg av et annet ord. Demonstrativ er på si side en funksjonell kategori som betegner ord som kan fungere både som pronomen og determinativ.

Referentene til demonstrativer kan være objekter, personer, handlinger, følelser, eller nær sagt det meste. Demonstrativene har disse varierte uttrykksformene og funksjonene til felles med negasjon, som også er en universell og frekvent kategori. I denne artikkelen argumenterer jeg for at demonstrativer og negasjonsuttrykk også har det til felles at de kan inngå i forsterkingssykluser.

Norske adnominale demonstrativer er grovt sett markert for to deiktiske distanser: proksimal (denne) og distal (den). Det semantiske trekket distanse er hovedsakelig relevant når referenten er lokalisert i de fysiske omgivelsene til diskursdeltakerne. I mer grammatikaliserte bruksmåter er denne kontrasten utviska (jf. paret den herre og den derre, som kan brukes uten stedsreferanse), og i denne artikkelen vil jeg ved hjelp av korpusanalyser kartlegge hvilke funksjoner disse nye demonstrativene har fått. 
På tvers av språk er demonstrativer hyppig innblanda i to diakrone prosesser: De er utsatt for grammatikalisering (bl.a. til artikler, personlige pronomen, subjunksjoner, se Diessel 1999), og de blir ofte forsterka gjennom tillegg av en demonstrativforsterker som her og der. Ulike forskere (som Greenberg 1978, van Gelderen 2011) regner grammatikaliseringa som den utløsende årsaken til forsterking, fordi demonstrativene må 'tilføres ny deiktisk kraft'. Her vil jeg i stedet argumentere for at sammenhengen mellom de to prosessene er omvendt, på den måten at fornying av demonstrativer gjennom forsterking kan katalysere grammatikaliseringa av gamle demonstrativer - dvs. " $\varnothing \mathrm{ke}$ " en endringsprosess som allerede er i gang.

Artikkelen er organisert slik: I avsnitt 2 presenteres det teoretiske grunnlaget og bakgrunnen for studien, før jeg i avsnitt 3 giør rede for kildegrunnlaget og analysemetodene. Deretter legger jeg i avsnitt 4 fram en korpusbasert unders $\varnothing$ kelse av bruksmåtene for komplekse demonstrativer i moderne norsk, og i avsnitt 5 drøfter jeg hvordan disse komplekse demonstrativene har utvikla seg. I avsnitt 6 argumenterer jeg for hvordan en nisjebasert og bruksbasert tilnærming kan bidra til å belyse de historiske prosessene grammatikalisering og forsterking.

\section{Teoretisk bakgrunn}

\subsection{Eksoforiske og endoforiske bruksmåter av demonstrativer}

Vi kan dele de norske komplekse demonstrativene inn i to hovedgreiner: en eksoforisk (diskursekstern) og en endoforisk (diskursintern), basert på Himmelmann (1996) og på Diessels (1999) typologi over demonstrativfunksjoner. De komplekse eksoforiske demonstrativene har hovedsakelig kort og etterstilt forsterker, som i (1). Den endoforiske varianten har derimot foranstilte (og ofte utvida) forsterkere, som i (2). Det er ikke noe skarpt skille mellom disse to greinene, og i overgangene mellom typisk eksoforisk og typisk endoforisk bruk kan en finne begge varianter (f.eks. ved symbolsk eksoforisk bruk som i (1)).

(1) Ee det stedet her er ganske lite (Nordisk dialektkorpus, heretter NDK, Oppdal)

(2) Ja ... Det er ikke de der spikerpistolene, nei (NDK, Landvik) 


\section{URd VindenEs}

Det er rimelig å anta at den eksoforiske funksjonen til de komplekse demonstrativene oppsto først, og at den endoforiske bruken er sekundær. En av grunnene er at kontrasten mellom proksimal (her) og distal (der), som ligger nær lokasjonsbetydninga til adverba her og der, alltid er opprettholdt i denne bruksmåten, i motsetning til i den endoforiske bruksmåten, hvor den er mindre tydelig. Den eksoforiske bruksmåten av demonstrativer er dessuten den mest 'grunnleggende' if $\varnothing$ lge Diessel (1999), siden det er den eneste deiktiske funksjonen som fins i alle verdens språk. Alle andre deiktiske funksjoner, som anaforisk deiksis eller diskursdeiksis, er utvidelser av denne funksjonen, og de har oppstått ved grammatikalisering.

Eksoforisk deiksis betyr ikke nødvendigvis konkret utpeking av et objekt eller en person i omgivelsene. En undertype er symbolsk eksoforisk referanse, til forskjell fra den gestbaserte, som innebærer konkret utpeking. Symbolsk eksoforisk deiksis brukes når man peker ut tider (denne uka her, den tida her), større områder (den byen her) eller andre ikke-synlige ting (den lufta her). I Nordisk dialektkorpus ser denne typen av deiksis ut til å være svært vanlig. Til tross for at referenten ikke er synlig, er det fortsatt snakk om eksoforisk referanse, ettersom kontrasten mellom distale og proksimale former er betydningsfull (jf. det året der vs. det året her). Noen av de første eksemplene på bruk av prenominalt her som vi kan se i skriftlige kilder, er med nettopp symbolsk eksoforisk referanse:

(3) Scriffuit war thetta her breff i Sarpsborgh (DN II: 1000, Sarpsborg, 1498)

(4) ... stadffeste wj nw thet kiøp ok giøre thet obryteligith effther then her dag (DN XIV: 514, Jämtland, 1525)

I tillegg til eksemplene i (3) og (4) kan en finne liknende eksempler som the ther breff (Vågå, 1487), then her tidh (Jämtland, 1530), thetta her breff (Veøy, 1499), thenne her rese (ukjent sted, ca. 1494), denne her skijck (Trondheim, 1554) og denne her dagh (Jämtland, 1545) (se også avsnitt 5.2). I disse eksemplene kan vi se flere svenskspråklige innslag (det kan uansett være vanskelig å skille norsk fra dansk og svensk på dette stadiet), og det er sannsynlig at konstruksjonen er lånt inn fra svensk, eller at den har blitt mer frekvent etter kontakt med svensk. Ifølge Svenska Akademins ordbok tilhører både den där og den här hovedsakelig talespråket også i svensk, og har gjort det "sedan början" (sjøl om det er uklart akkurat når 
det er). Derfor finner man konstruksjonen først og fremst i gjengitt tale i de eldste kildene, f.eks.:

(5) Kära jungfru Kirstin, låt inte den där flickan komma för mina ögon. (SAOB, den där. Eksempelet er fra Agneta Horns lefverne, ca. 1657).

Som vi ser av det svenske eksempelet i (5), er det ikke nødvendigvis snakk om eksoforisk bruk her, men kan være en videre grammatikalisert endoforisk bruksmåte. Det er mulig å finne enda tydeligere eksempler på dette: Hwadh må then danna för en danker [ = en dagdriver] wara? (SAOB, den där, eksempelet er fra 1645). Denne bruksmåten av demonstrativer, og opphavet til den, blir diskutert i avsnitt 4.6.

Et s $\varnothing \mathrm{k}$ i eldre svensk prosa gjennom KORP (Borin et al. 2012) viser at komplekse demonstrativer som thetta här dukker opp allerede på 1400tallet, og da med en symbolsk eksoforisk bruksmåte:

(6) Tha ropar ban oc sigher Hwa lagdhe thetta här (Pentateuchparafrasen, 1400-1450)

Det er ikke uventa at det er nettopp den symbolske eksoforiske bruken som dukker opp først i de historiske kildene, og ikke den gestbaserte, ettersom de emfatiske kontekstene for demonstrativer er muntlige. Bruk av demonstrativer med gestbasert eksoforisk referanse forutsetter at det er noe fysisk i nærheten å peke på, og i skriftmediet forutsetter det at konteksten er gjengitt tale. Det fins riktignok en del direkte sitater og muntlige trekk i noen diplomer, men tallet på komplekse demonstrativer i disse kildene er nokså beskjedent (og det er det fortsatt i moderne norsk, jf. avsnitt 4.3 om bruksfrekvens i skriftlige vs. muntlige kilder). Den symbolske eksoforiske bruken vi ser eksempel på i (3) og (4), er derfor antakelig det nærmeste vi kommer den opphavlige bruken av komplekse demonstrativer i norsk, og denne bruken ser vi fortsatt i moderne norsk:

(7) Så, ehm, vi håper jo fint ... bestille fint vær til den dagen der, da (NDK, Tana)

Komplekse demonstrativer med foranstilt og (ofte) utvida, dvs. flerstava, forsterker (som derre, derrane) ser ut til være særlig assosiert med pragmatikaliserte bruksmåter, særlig bakgrunnsdeiksis (recognitional deixis), 


\section{URD VINDENES}

som er beskrevet av Lie (2010). Pragmatikalisering betyr at ordet gjennom grammatikalisering får spesielle pragmatiske diskursfunksjoner. Det som kjennetegner den bakgrunnsdeiktiske bruksmåten, er at referenten ikke har blitt nevnt i samtalen ennå, men at talerne kjenner til hva eller hvem det er snakk om (de har altså bakgrunnskjennskap til referenten). Det komplekse demonstrativet sånn derre brukes med en liknende funksjon, sj $\varnothing 1$ om referenten i dette tilfellet er ubestemt. Lie (2008) har beskrevet denne bruksmåten, og påpeker at den brukes i tilfeller hvor sånn har som funksjon å markere at taleren er usikker på om mottakeren er kjent med referenten (f.eks. en sånn $M P_{3}$ ). Sammenhengen mellom de pragmatikaliserte funksjonene til sånn herre/derre og den herre/derre er blant annet at de begge kan fungere som såkalte solidaritetsmark $\varnothing$ rer ("markers of solidarity", etter Lakoff 1974). Sånn herre/derre på den ene sida kan signalisere en antakelse om at begge/alle samtalepartnerne ikke er så godt kjent med den spesifikke referenten, mens den herre/derre på den andre sida kan signalisere at begge/alle samtalepartnerne kjenner til den spesifikke referenten. Et annet fellestrekk for demonstrativer som blir forsterka av herre/derre, er at referenten er spesifikk, og blir individuert. I avsnitt 4.3 og 4.4 presenterer jeg korpusanalyser som underbygger disse påstandene.

\subsection{Fornying av grammatiske elementer}

Det er velkjent at funksjonsord og grammatiske uttrykk typisk blir til gjennom prosessen grammatikalisering, dvs. at et språklig element går fra leksikalsk til grammatisk eller fra grammatisk til mer grammatisk status (Kuryłowicz 1969). Demonstrativer, og delvis også negasjonsmark ører, ser derimot ut til å være et unntak fra dette. Ifølge en omfattende typologisk undersøkelse (Diessel 1999) fins det overraskende nok lite evidens for at demonstrativer i verdens språk har utvikla seg fra leksikalske klasser som verb eller substantiv. De har heller ikke utvikla seg fra andre funksjonsordklasser, men kan spores tilbake til gamle deiktiske røtter. Ifølge Diessel blir demonstrativer altså ikke til ved grammatikalisering aleine, slik grammatiske uttrykk oftest gjør, men blant annet ved forsterkingssykluser. Også andre grammatiske kategorier kan inngå i slike sykluser.

Den forsterkingssyklusen som kanskje er mest kjent og best studert, er negasjonssyklusen, som også kalles Jespersens syklus. Prosessen hvor negasjonsmarkører går fra en partikkel til to, og så tilbake igjen til én, 
blei identifisert som en syklus av Dahl (1979), men prosessen er beskrevet av Jespersen (1917). Den enkleste framstillinga av syklusen har tre stadier, og skoleeksempelet på negasjonsforsterking er den franske negasjonen (ne) pas, som opprinnelig betydde 'ikke et skritt' (eksempelet er fra Jespersen 1917: 8).

$\begin{array}{lllll}\text { a. } & \text { Je } & \text { ne } & \text { sais. } & \\ & \text { jeg } & \text { NEG } & \text { veit } & \\ \text { b. } & \text { Je } & \text { ne } & \text { sais } & \text { pas. } \\ & \text { jeg } & \text { NEG } & \text { veit } & \text { lite-skritt } \\ & & & & \\ \text { c. } & \text { Je } & \text { sais } & \text { pas. } & \\ & \text { jeg } & \text { veit } & \text { NEG } & \end{array}$

'Jeg veit ikke'

Flere liknende utviklinger har funnet sted i en rekke språk (se f.eks. Hansen 2011).

Forsterkningssykluser som Jespersens syklus er en type grammatisk endring, men grammatikk kan dannes eller fornyes på flere måter. Lehmann (2015: $22 \mathrm{ff}$.) skiller mellom renovasjon og innovasjon av grammatiske elementer. Endringer som innebærer innovasjon går typisk inn under Kuryłowicz' definisjon nevnt over (altså at et språklig element går fra leksikalsk til grammatisk eller fra grammatisk til mer grammatisk status, f.eks. gjennom at det får mer skjematisk betydning eller taper syntaktisk frihet). Når et grammatisk element blir til gjennom innovasjon, kan det enkelt settes opp som at ' $x$ grammatikaliseres til y', og et eksempel er endringa der det latinske demonstrativet ille 'den' grammatikaliseres til det franske personlige pronomenet il 'den/han'.

Renovasjon hos Lehmann (2015) er derimot en endring der 'y erstatter x', og et eksempel på dette er erstatninga av det latinske ille med det franske ce(lui) là (ibid. s. 22). Disse to endringstypene - grammatikalisering og fornying - er distinkte diakrone endringstyper, der den førstnevnte danner nye grammatiske kategorier, mens den sistnevnte i prinsippet konserverer dem. Men grammatikalisering behøver ikke danne noe helt nytt, og fornying er sjelden rein konservering av en grammatisk funksjon - det vil si at en gammel og en fornya konstruksjon ikke er funksjonelt identiske med hverandre. Dette skyldes bl.a. at de nye og 


\section{URd VindenEs}

gamle konstruksjonene (x og y) sameksisterer over kortere eller lengre tid (gjennom det som kalles lagdeling, se Hopper og Traugott 2003: 49), og at de dermed er i paradigmatisk konkurranse. Når to nær-synonyme konstruksjoner står i paradigmatisk opposisjon, vil de typisk bli assosiert med hver sin spesialiserte funksjon. Dette ser vi et eksempel på med de norske demonstrativene den og den der, som vi kommer tilbake til i avsnitt 4.4.

Fornying (renovasjon) av grammatiske elementer kan enten skje gjennom erstatning eller forsterking. Ved erstatning vil 'y overta for $\mathrm{x}$ ', og et eksempel på dette kan være fornyinga av det gammalengelske pre-modale verbet purfan 'turve, trenge, måtte' med verbet need i middelengelsk (se Loureiro-Porto 2013) - her er det ikke involvert noe forsterkningselement på noe tidspunkt i endringa.

Ved fornyelsesprosessen forsterking inngår det forsterkende ord eller former i prosessen: 'y overtar for x via stadiet xy'. Dette "nye" forsterkerelementet er gjerne et grammatikalisert ord, jf. negasjonsmark $\varnothing$ ren pas i fransk i eksempel (8) over, som er desemantisert, dvs. at det taper den leksikalsk-semantiske betydninga, og får en mer skjematisk eller generell betydning. Det skjedde gjennom at det minimerende ordet pas 'steg' blei analysert som en del av nektingsuttrykket, slik at nektinga uttrykkes gjennom hele konstruksjonen ne V pas. På dette stadiet kan pas kalles en forsterker. I muntlig fransk droppes gjerne ne, slik at pas har tatt over funksjonen som negasjonsmark $\varnothing$.

Tradisjonelle grammatikaliseringsstudier tar gjerne utgangspunkt i og følger et ord eller en form, f.eks. substantiv > preposisjon, og unders $\varnothing$ ker hvilke semantiske, pragmatiske og strukturelle endringer denne formenheten gjennomgår (gjerne med utgangspunkt $i$ "diagnostiske" kriterier eller parametere som foreslått av Lehmann 2015 eller Haspelmath 2004). Moderne grammatikaliseringsstudier, innafor generative så vel som konstruksjonsgrammatiske rammeverk, tar oftere utgangspunkt i fornying av grammatiske kategorier (f.eks. Trousdale 2014, van Gelderen 2011). Også i eldre arbeider om grammatikalisering har det blitt det argumentert for at det blir for snevert å fokusere på det grammatikaliserende elementet aleine, ettersom det aldri gjennomgår grammatikalisering utafor bestemte språklige kontekster (f.eks. Bybee, Perkins og Pagliuca 1994: 26, og Himmelmann 2004: 31 ff.). I studier av fornyingsprosesser er det særlig funksjonen, eller den såkalte funksjonelle nisjen (se Aronoff 2016), f.eks. deiksis eller nekting, som er utgangspunktet for analysen - 
ikke ordet eller morfemet. Funksjonelle nisjer er ikke forutbestemt, og de varierer ofte både på tvers av språk og på tvers av tid. For eksempel fins det ikke noen funksjonell nisje for 'der-oppe' eller 'der-nede' for demonstrativer i norsk, sjøl om demonstrativer fra bl.a. inuktitut har det (Diessel 1999: 49). Likevel kan nisjeperspektivet være et mer fruktbart utgangspunkt for å studere forsterkingssykluser enn det de tradisjonelle formbaserte modellene er. En grunn er at slike sykluser ofte involverer ulike former i ulikt antall på de forskjellige stadiene. Utviklinga av den franske negasjonsmark $\varnothing$ ren pas regnes gjerne også som et skoleeksempel på grammatikalisering (i tillegg til sykliske endringer). Formbasert grammatikaliseringsteori kan si oss mye om utviklinga av forsterkeren pas, men ikke så mye om endringa av hele nektingsuttrykket ne, og seinere ne ...pas.

Et av problema med nisjetilnærminga til syklisk endring, som kanskje er et vanlig problem med funksjonelle tilnærminger generelt, er at man lett ender opp med teleologiske forklaringer på språkendringer. Når demonstrativer eller negasjoner fornyes gjennom forsterking, har det noen ganger blitt forklart med at disse elementene trenger å fornyes enten formelt eller funksjonelt fordi de har blitt redusert gjennom frekvent bruk eller gjennom grammatikalisering (reduksjon først, forsterking etterpå). Slike tilnærminger har også blitt brukt om negasjonsforsterking, og de går minst tilbake til Jespersens tid:

[T] he original negative adverb is first weakened, then found insufficient and therefore strengthened, generally through some additional word, and this in its turn may be felt as the negative proper and then in course of time be subject to the same development as the original word. (Jespersen 1917: 4)

En rimelig tolkning av sitatet over er at Jespersen anser negasjonsforsterking som motivert av behov for å reparere en svekka negasjonsmarkør, som igjen innebærer at en må anta at det fins stadier hvor språksystemet har hull. Beslekta tilnærminger er fortsatt å finne i nyere forskningslitteratur:

There are also grammatical elements that are reanalyzed into more grammatical ones. These changes necessitate renewal and the entire process is sometimes referred to as a linguistic cycle. (van Gelderen 2011: 5-6) 


\section{URD VINDENES}

I sitatet over kan det se ut til at forfatteren antar at fornying av funksjonelle nisjer skjer i rekkefølgen tap > fornying. Problemet blir da at resultatet tolkes som motivasjonen bak endringa. Verken språksystemet eller språkbrukerne ser fram $i$ tid, og det fins dessuten neppe noen språk som mangler eller har dysfunksjonelle demonstrativer eller negasjonsmark $\phi$ rer - disse er funksjonelle kategorier som alltid fins i alle språk, altså universalier. Slike forklaringer snur opp ned på årsak-virkning-forholdet når de sier at behov for fornying er motivasjonen bak forsterking. Tvert om er fornyinga resultatet av forsterking, mens motivasjonen bak endringa nødvendigvis må være en annen.

For å finne motivasjonen bak demonstrativforsterking må vi i stedet se på de kontekstene hvor forsterking har en tendens til å oppstå, som blant andre Willis et al. (2013) har argumentert for i analysen av negasjonssykluser. I avsnitt 5 presenteres en analyse av demonstrativforsterking i norsk, og i avsnitt 6 drøfter jeg hvilke implikasjoner disse endringene har for hvilken tilnærming man velger.

\section{Empiri og metode}

\subsection{Datagrunnlag}

Dataene i analysen er hovedsakelig henta fra den norske delen av Nordisk dialektkorpus (NDK). NDK er et elektronisk korpus som er bygd opp av 2,8 millioner ord fra opptak av spontantale over hele Norden (Johannessen et al. 2009). Siden korpuset er grammatisk tagga, kan man lage søkestrenger med både spesifikke leksemer og generelle ordklasser. I enkelte analyser (se avsnitt 3.2) henter jeg også data fra spontantalekorpusene Norsk talespråkskorpus - Oslo-delen (NoTa), TAUS - Talemålsunders $\varnothing$ kelsen i Oslo og BigBrother-korpuset.

For å få relevante treff på komplekse demonstrativer i korpusene, brukte jeg søkestrengene "determinativ/pronomen/sånn/slik (lemmaform $)+$ der/derre/her/herre" og "determinativ/pronomen/sånn/slik (lemmaform) + o,1 (dvs. at det kan være opptil ett ord på denne plassen) + substantiv + der/derre/her/herre", for å finne demonstrativer med henholdsvis prenominale (den her boka, ev. demonstrativ med pronominal funksjon: den derre) eller postnominale forsterkere (den boka her). Irrelevante treff blei sortert vekk (eksempler er duplikater eller treff der 
her/der ikke hadde forsterkerfunksjon, men adverbial funksjon: så satt bun der).

Artikkelen tar også opp forsterking av demonstrativer fra et diakront perspektiv, men siden en del forsterkingsvarianter (f.eks. forsterking med her/der) og konteksten for forsterking er svært tett knytta til tale, er det vanskelig å finne nok historiske eksempler til å gjøre kvantitative analyser. Den elektroniske varianten av arkivet Diplomatarium Norvegicum viser kun få eksempler på adnominal bruk av her-og der-varianter i mellomnorsk. For å kunne si noe mer om den historiske utviklinga av komplekse demonstrativer må man også basere seg på det vi veit om liknende konstruksjoner fra andre språk, om ulike varianter i moderne norske dialekter, og om generelle egenskaper ved demonstrativer. Analysen drar særlig nytte av Diessels (1999) omfattende typologisk-diakrone studie av demonstrativer, og argumentene baserer seg dessuten på data som er lagt fram i Vindenes (2018a: 172-175).

\subsection{Metode: distinktiv kolleksemanalyse}

Formålet med denne unders $\emptyset$ kelsen er dels å gi en beskrivelse av bruksområdene til og utbredelsen av komplekse demonstrativer i norsk, dels å presentere en mulig historisk utvikling. Kollostruksjonsanalyser hvor en måler hvilke substantiv ulike demonstrativer oftest forekommer sammen med, kan gi verdifulle hint om de semantiske egenskapene ved de ulike demonstrativene. I dette avsnittet beskriver jeg måten jeg annoterte korpusdataene på, og framgangsmåten i kollostruksjonsanalysen.

For å kartlegge funksjonene som skiller de ulike demonstrativene, har jeg gjort en distinktiv kolleksemanalyse, som er en undertype av kollostruksjonsanalyser utvikla av Stefanowitsch og Gries (2003). I en slik analyse tar man utgangspunkt i flerordskonstruksjoner (i dette tilfellet demonstrativ + substantiv, f.eks. den der N) og måler den såkalte tiltrekningsstyrken de ulike konstruksjonene har på leksemene som fyller de åpne plassene i konstruksjonen (altså et kolleksem, f.eks. "greia" eller "tingen” på N-plassen i den der N). Tiltrekningsstyrke er altså et mål på hvor ofte visse ord eller konstruksjoner forekommer i en gitt konstruksjon, sammenlikna med en annen konstruksjon. For eksempel kan en sammenlikne hvor ofte substantivformen greia forekommer sammen med den versus med den derre, og unders $\varnothing$ ke om tiltrekningsstyrken er st $\varnothing$ rre for den ene eller andre konstruksjonen. Selve målinga gjøres ved å telle og sammenlikne antallet forekomster i ulike mønstre i korpus. For å få 


\section{URD VINDENES}

et tall på hvorvidt et ord er signifikant "tiltrukket" en gitt konstruksjon, regner man ut en log-transformert $p$-verdi. ${ }^{1}$ Er dette tallet under $-1,3$ eller over 1,3 for et gitt leksem, betyr det at det er signifikant sterkere tiltrukket den ene eller andre konstruksjonen.

I en tradisjonell kollokasjonsanalyse måler man tiltrekninga ulike leksem har til hverandre i et korpus. Forskjellen på en kollokasjonsanalyse og en kollostruksjonsanalyse er at sistnevnte er en videreutvikling med et konstruksjonsbasert utgangspunkt. Metoden skal være bedre egna enn den tradisjonelle kollokasjonsanalysen til å fange opp nivåene i konstruksjonshierarkier. For eksempel vil en kollostruksjonsanalyse kunne egne seg til å sammenlikne beslekta konstruksjoner som den $N$ og den derre N.

Kollostruksjonsanalyse, og mer spesifikt distinktiv kolleksemanalyse, har flere egenskaper til felles med bruksprofilanalyse ("behavioral profiling", Gries 2010). Men mens hensikten med en bruksprofilanalyse er å utforske den leksikalske semantikken til et leksem, er hensikten med den distinktive kolleksemanalysen å unders $\varnothing$ ke en grammatisk konstruksjon.

Målet med den distinktive kolleksemanalysen av ulike demonstrativkonstruksjoner (enkle, som den $N$, og doble, som den derre $N$ ) er å peke ut semantiske egenskaper som er distinkte for hver av konstruksjonene, og som kan bidra til å klargjøre hvilke funksjoner de har. Dersom et substantiv er signifikant sterkere trukket mot den ene eller andre konstruksjonen, er det distinktivt. For å måle dette må man først telle opp antallet ganger de forskjellige substantivene brukes i hver av konstruksjonene, og deretter regne ut hvilke substantiver som har en tendens til å trekkes mot en bestemt konstruksjon (jf. fotnote 1).

Korpuss $\varnothing$ k i NDK, NoTa og BigBrother ga 1766 relevante treff på adnominale komplekse demonstrativer med den eller denne (f.eks. den der teltturen, dette året her), $822 \mathrm{med}$ sånn/slik, og $133 \mathrm{med}$ han/hun. I til-

1. Den statistiske signifikansen av kollokasjonsstyrken er regna ut ved hjelp av en Fisher exact-test, og cut-off for å regne et kolleksem som distinktivt for en gitt konstruksjon er en $p$-verdi på o,05 (Levshina 2015: $245 \mathrm{ff}$.)

Målet på distinkthet er en log-transformert $p$-verdi $(\log p)$, med signifikansverdi på 1,3 og -1,3 (med 10 som grunntall for logaritmen). Det svarer omtrent til en $p-$ verdi på 0,05 . Utregningene blei gjort i $\mathrm{R}$ etter metoden som er beskrevet av Levshina (2015: 242 ff.). Fordelen med å bruke Fisher exact-test i kollostruksjonsanalyser er at den, i motsetning til f.eks. khikvadrattesten, kan brukes på relativt små datasett fordi den bruker kategoriske data (i dette tilfellet: hvorvidt et leksem forekommer i en konstruksjon eller ikke). 
legg inkluderer unders $\varnothing$ kelsen konstruksjoner med enkle demonstrativer for å kunne utføre kollostruksjonsanalyser: 1246 tilfeller med den/denne, 4600 med sånn, og 1829 med han/hun. For å finne kolleksemer til de ulike demonstrativvariantene var det viktig å ha så mange treff som mulig, så i denne analysen blei data fra alle tre korpus brukt. I analysen av den geografiske spredninga av de ulike demonstrativvariantene var det bare NDK-treffa som blei brukt. Her er også pronominale komplekse demonstrativ tatt med i unders $\varnothing$ kelsen (f.eks. se på det der) - det blei henta ut 1001 relevante eksempler (av 3272 treff) fra NDK.

Treffa fra NDK blei annotert etter disse variablene: grunndemonstrativ (den, det, de, denne, dette, disse, han, hun, sånn, slik eller $\varnothing)$, lengde på forsterker (enstava, to- eller flerstava), forsterkervariant (proksimal med $b$-, distal med - $d$, ubestemmelig), morfologiske egenskaper ved ev. substantiv (enkelt eller sammensatt), og grovinndelt dialektområde (nordnorsk, trøndersk, vestnorsk, $\varnothing$ stnorsk). Resultatene av analysen blir presentert under avsnitt 4.

\section{Komplekse demonstrativer med her/der i moderne norsk}

\subsection{Bakgrunn}

I moderne norsk kan demonstrativene den, denne, han, hun og sånn (og til dels slik) forsterkes av her og der: den der boka, han der mannen. Denne forsterkingsprosessen har i de fleste dialekter ikke kommet så langt at vi ikke lenger kan dele opp uttrykk som den der i bestanddelene den og der (med unntak av f.eks. meldalsmålet, se avsnitt 5.1), men en analyse av hver av disse bestanddelene kan likevel ikke forutsi funksjonen til hele uttrykket, for eksempel når det brukes i en ytring som den der boka du snakka om. Funksjonen til uttrykket den der er analyserbar, men mindre komposisjonell enn f.eks. den (boka) der, hvor der ikke er like redusert, og fortsatt har klar lokativ betydning. I visse dialekter har prosessen gått enda videre, og vi har fått nye demonstrativer som verken ser ut til å være komposisjonelle eller analyserbare lenger (dinner og detter i meldalsmålet, se avsnitt 5.1).

Forsterking med stedsadverb er svært vanlig i germanske språk, og man finner det i engelske dialekter, tyske dialekter, skandinavisk og afrikaans (se Vindenes 2018b: 648 ff.), og dessuten i språk som fransk, romansk, polsk og gresk. Noe som ser ut til å gå igjen på tvers av mange 


\section{URD VINDENES}

av disse språka, er at komplekse demonstrativer virker noe vanligere i folkelige dialekter enn i standardspråk - dette gjelder blant annet i norsk, tysk og engelsk. Grunnen til at fenomenet er mindre vanlig i standardspråk, kan være at det doble uttrykket av deiksis virker overflødig, og at det derfor ikke er med i skrift, eller det kan henge sammen med den diskursdeiktiske funksjonen til disse demonstrativene. Dersom de komplekse demonstrativene for eksempel ofte brukes om "private" og unike referenter, eller til å peke ut konkrete objekter i omgivelsene (se avsnitt 4.3), er det lite overraskende at de ikke forekommer ofte i tradisjonelle skriftlige tekster.

Fenomenet komplekse demonstrativer med her/der i norsk, som i den der boka eller den boka der, har blitt beskrevet i Norsk referansegrammatikk (Faarlund et al. 1997) og av Myklebust (2012) og Vindenes (2018a, b), og har ellers fătt omtale i en rekke forskningsartikler om demonstrativer (Dyvik 1979; Lødrup 1982; Strahan 2008; Johannessen 2006, 2012; Lie 2008, 2010; Venås 2012). Den historiske utviklinga av komplekse demonstrativer har fått en viss oppmerksomhet i litteratur om sykliske endringer og grammatikalisering (van Gelderen 2011), og ellers i arbeider om skandinaviske pronomensystem (Reinhammar 1975).

\subsection{Bruksfrekvens i tale og skrift}

Komplekse demonstrativer med her/der er relativt vanlige i muntlig norsk. I den norske delen av Nordisk dialektkorpus forekommer demonstrativer ofte med slike forsterkere: Demonstrativet denne brukes med en foranstilt forsterker (f.eks. denne her saken) hele $20 \%$ av gangene denne forekommer, og med en etterstilt forsterker (denne saken her) 3\% av gangene. På andre plass kommer den, som brukes $8 \%$ med foranstilt og $2 \%$ med etterstilt forsterker, mens sånn brukes med foranstilt forsterker $9 \%$ av gangene det brukes. Slik brukes sjelden med forsterkere (bare $2 \%$ av forekomstene), og det er vanskelig å komme med noen mer avansert forklaring på dette enn at det kanskje skyldes en tendens til at sliker mer typisk for konservative dialekter. Av de fire dialektområdene $\emptyset$ stnorsk, nordnorsk, vestnorsk og trøndersk er det nordnorsk som klart bruker komplekse demonstrativer oftest, med trøndersk på en andreplass (se ill. 1). Grunnen til at komplekse demonstrativer har en så mye høyere frekvens i nordnorsk, kan være at de også brukes med grammatikalisert funksjon, som bestemt artikkel eller grammatikalisert pronomen (se av- 
snitt 4.5), som er mer frekvente i løpende tekst enn demonstrativfunksjoner.

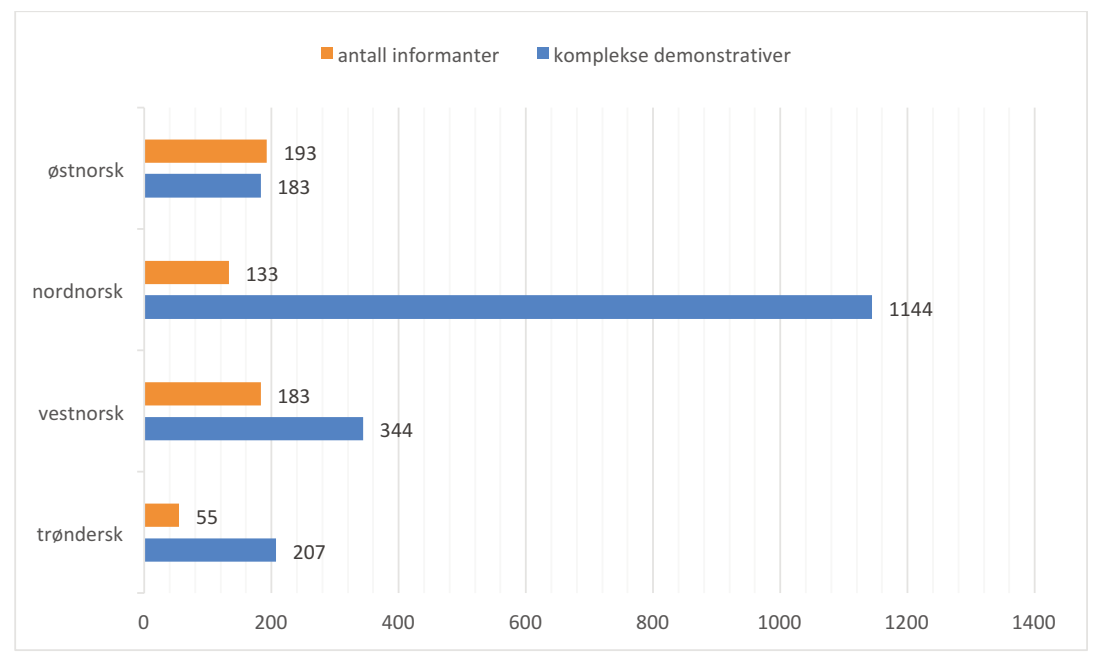

Illustrasjon 1: Distribusjon av komplekse demonstrativer ipronominal og attributiv posisjon med foranstilt forsterker, sammenlikna med tallet informanter for bver dialekt.

Kollokasjonsstyrken mellom den og der er omtrent 13 ganger høyere i Nordisk dialektkorpus enn i Leksikografisk bokmålskorpus. Denne forskjellen kan som nevnt i avsnitt 4.1 bero på at tillegget av her/der virker redundant, og at man generelt vil unngå redundans når man skriver. Men det kan også henge sammen med at bruken av demonstrativer generelt $\emptyset$ ker i muntlig språkbruk på grunn av at det åpner opp for konkret utpeking av ting i omgivelsene. En annen grunn kan være at den mest pragmatikaliserte bruken av den der signaliserer et slags bånd mellom samtalepartnerne (de deler spesifikk kunnskap, se avsnitt 4.3), og at denne bruken nødvendigvis vil være mer knytta til uformell og typisk muntlig språkbruk (jf. Lakoff 1974: 347). 


\section{URd VindenEs}

\subsection{Resultatet av den distinktive kolleksemanalysen}

4.3.1 Hva skiller den(ne) her/der $N$ fra enkle demonstrativer?

To distinktive kolleksemanalyser av adnominale demonstrativer i Nordisk dialektkorpus og substantivene de står til, styrker antakelsen om at de komplekse demonstrativene med foranstilt forsterker har bakgrunnsdeiktisk funksjon (peke ut referenter som samtalepartnerne har felles, privat kunnskap om), og at variantene med etterstilt forsterker har symbolsk eksoforisk funksjon (peke ut ikke-synlige referenter, som $u k e$ ). Komplekse demonstrativer med foranstilt forsterker (den $\operatorname{der} N$, den her $N$, med ulike varianter av forsterkeren) forekommer signifikant oftere med substantivet greie (i formene greia/greiene) enn enkle demonstrativer gjør. De enkle demonstrativene (den, denne), på sin side, forekommer signifikant oftere med orda gangen, tida, skolen, måten og dagen, som vi ser i ill. 2 (for beskrivelse av metoden, se avsnitt 3.2).

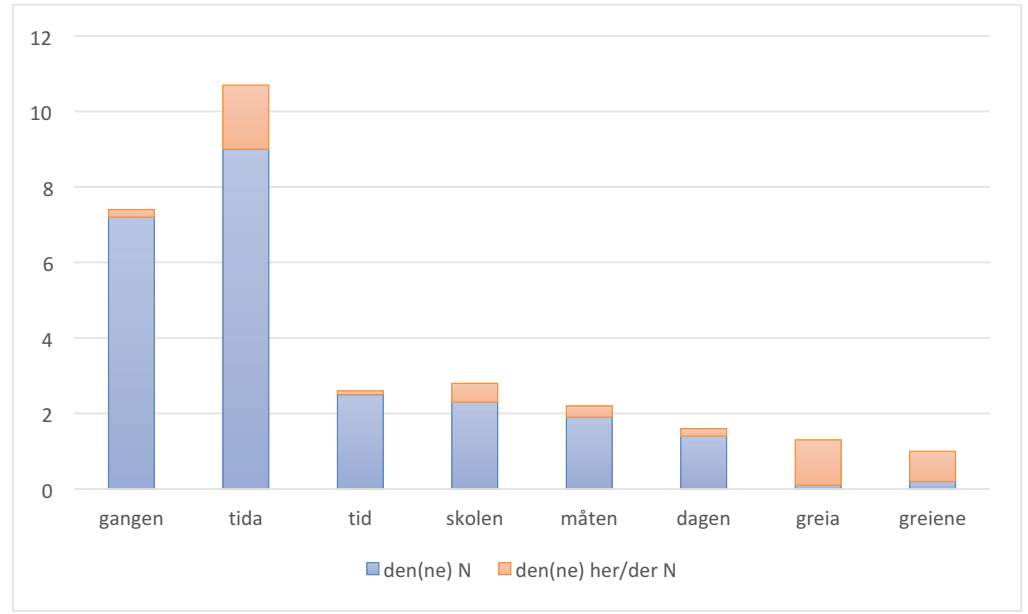

Illustrasjon 2: Distinktive kolleksemer for enkle og komplekse demonstrativer med foranstilt forsterker (oppgitt i prosent av alle gangene henholdsvis den(ne) $\mathrm{N}$ og den(ne) her/der $\mathrm{N}$ forekommer).

Dette styrker antakelsen om at komplekse demonstrativer med foranstilte forsterkere har mer bakgrunnsdeiktisk og pragmatikalisert funksjon enn enkle demonstrativer, siden greie betegner noe mer generelt enn 
de mindre vage substantivene gangen, tida osv. gjør. Et typisk eksempel er:

(9) Men viss du har råd til alt det der greiene, så har du vel gjerne råd til at noen kan komme og vaske det for deg og, så (NDK, Suldal)

4.3.2 Hva skiller den(ne) $N$ her/der fra enkle demonstrativer?

I den andre distinktive kolleksemanalysen blei komplekse demonstrativer med etterstilt forsterker sammenlikna med enkle demonstrativer. Analysen viser at også konstruksjonen med etterstilte forsterkere tiltrekker seg greia/greiene i signifikant grad (se ill. 3). I tillegg brukes denne konstruksjonen ofte med formene huset, greiene, området, tingene, rommet, kommunen, året, uka og dagene - med andre ord referenter som typisk blir utpekt med symbolsk eksoforisk referanse (f.eks. den uka her). Den etterstilte forsterkeren kan i en slik funksjon bidra med emfatisk fokus på proksimal eller distal eksoforisk referanse. Et eksempel på det er:

(10) lurer på hva folk kommer til s- t- syns når de hører den samtalen her (NDK, Time)

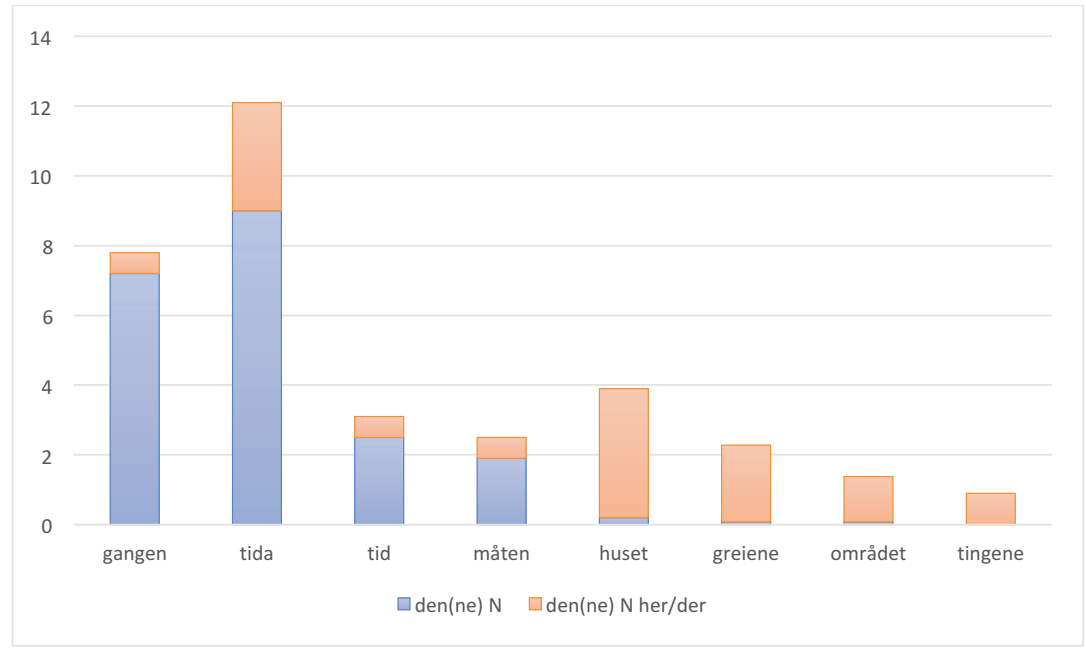

Illustrasjon 3: Distinktive kolleksemer for enkle og komplekse demonstrativer med etterstilt forsterker (oppgitt i prosent av alle gangene henholdsvis den(ne) $\mathrm{N}$ og den(ne) $\mathrm{N}$ her/der forekommer). 
Ellers viser det seg at formene gangen, tida, og måten, og dessuten dialekten, også her forekommer hyppigere sammen med enkle demonstrativer enn med komplekse (se ill. 3).

4.3.3 Hva sier kolleksemanalysen om funksjonene til komplekse demonstrativer?

Den distinktive kolleksemanalysen har påvist noen forskjeller i hvilke substantiv som er distinktive for de ulike demonstrativene i norsk: den(ne)her/der $N$ brukes mer med det muntlig pregede substantivet greia, som typisk kan brukes om lavt tilgjengelige referenter - dvs. at de ikke er lette å hente fram i den umiddelbare konteksten (de har low accessibility). Konstruksjonen den(ne) $\mathrm{N}$ her/der brukes mye med substantiv som huset, området, tingene m.m., som kan være typiske for symbolsk eksoforisk deiksis. Videre i dette avsnittet vil jeg trekke inn det såkalte individueringshierarkiet for å drøfte hva slags rolle komplekse demonstrativer spiller i å individuere referenter.

Et av fellestrekka mellom de pragmatikaliserte bruksmåtene av demonstrativene sånn og den at de bidrar til å individuere referenten. I individueringshierarkiet (Siemund 2008: 145), som er en variant av animathetshierarkiet, er det slik at referenter som er iboende individuerte, står aller $\emptyset$ verst (f.eks. Gud, sola), mens referenter nederst i hierarkiet er iboende vanskelige å individuere (f.eks. enkelte abstrakter som hat). Det er altså medlemmene i midten av hierarkiet som i størst grad lar seg 'manipulere' opp og ned hierarkiet, og ifølge Enger og Nesset (2011: 204-205) kan også innovasjoner skje i midten før de sprer seg i leksikon enten 'opp' eller 'ned' hierarkiet - de må altså ikke starte фverst eller nederst. Demonstrativer, og særlig de komplekse demonstrativene, kan brukes med bakgrunnsdeiktisk funksjon (jf. avsnitt 2.1) og i en slik kontekst er referenten altså identifiserbar og kjent for mottakeren, men ikke aktivert i samtalen. Komplekse demonstrativer som den der kan tvinge fram en høyere individuering av referenter som huset, området osv. Som vi ser i ill. 3, er gangen, tida, måten og dialekten statistisk sett mer trukket mot enkle demonstrativer enn mot komplekse. En mulig årsak til dette kan være at referanse til f.eks. tida med et komplekst demonstrativ ville ha implisert en tolkning av en veldig avgrensa (eller individuert) tidsperiode, eller at det ville implisert en understreking av kontrast til en annen avgrensa tidsperiode. 
Når språkbrukere bryter med konvensjonene i språket, kan det skape humoristiske effekter, og slik er det også med komplekse demonstrativer. Demonstrativer, og særlig komplekse demonstrativer, brukes altså sjelden med referenter høyt oppe i individueringshierarkiet, for referentene som befinner seg der, er allerede individuerte. Om man bryter denne konvensjonen, og f.eks. omtaler mannen sin som han derre mannen min, får man en ironiserende effekt nettopp på grunn av at man bruker et signal om at referenten egentlig hører til litt lenger nede i hierarkiet, og ikke er så framtredende. Dette kommer jeg tilbake til i avsnitt 4.5.

\subsection{Morfologiske egenskaper og litt om produktivitet}

En analyse av de morfologiske egenskapene ved substantivene som tiltrekkes til de komplekse demonstrativene med foranstilt forsterker (den $\operatorname{der} N$ ), viser at substantivene svært ofte er sammensetninger, i motsetning til substantivene som står til enkle demonstrativer (se ill. 4). Dessuten er substantivene i de komplekse demonstrativ-konstruksjonene ofte hapax legomena (782 ganger i NDK), altså ord som kun forekommer én gang i korpuset. Eksempler på kolleksemer som både er hapaxer og sammensatte, er tyskgreiene, Lion-kalenderen, modemtingen, maneteksplosjonen, sommertorsken. Enkle demonstrativer brukes naturligvis også ofte med hapaxer, men til forskjell fra komplekse demonstrativer er ratioen mellom hapaxer og antall tokens lav: 0,78 for komplekse demonstrativer (419 av 535) vs. o,28 for enkle demonstrativer (1167 av 4188). Derfor har komplekse demonstrativer en høyere såkalt potensiell produktivitet (se Baayen 2009: 902) enn enkle demonstrativer.

Produktivitet kan defineres på ulike måter, og det fins også en rekke måter å måle det på, med ulik grad av spesifisitet (for en oversikt, se Barðdal 2008). Ved å måle typefrekvens, tegnfrekvens (token frequency) og antall hapaxer kan man sammenlikne ulike tegn på produktivitet. Konstruksjoner som har lav tegnfrekvens, men mange hapaxer, har som nevnt høy potensiell produktivitet, som vil si at de har et potensial for å ekspandere, eller å bli produktive. Ei rein opptelling av hapaxer er derimot et mål på den ekspanderende produktiviteten (Baayen 2009: 905), som forteller at en konstruksjon rett og slett brukes ofte og med mange ulike kolleksemer. Enkle demonstrativer har en høy ekspanderende produktivitet - de brukes ofte, og de brukes ofte med ulike kolleksemer, men de har som nevnt over en lavere potensiell produktivitet enn kom- 


\section{URd VindenEs}

plekse demonstrativer, og brukes i større grad med det samme substantivet igjen og igjen (f.eks. den tida, den gangen).

Den statistiske forskjellen i potensiell produktivitet styrker påstanden om at komplekse demonstrativer med foranstilt forsterker har som funksjon å hente fram ikke-saliente og gjerne spesifikke og private referenter. Langt fra alle sammensetninger eller hapaxer i et korpus er faktiske nydannelser, og de refererer heller ikke nødvendigvis til spesifikk privat informasjon, men den statistiske forskjellen på de to kategoriene (enkle og komplekse demonstrativer) antyder likevel at de oftere brukes på den måten.

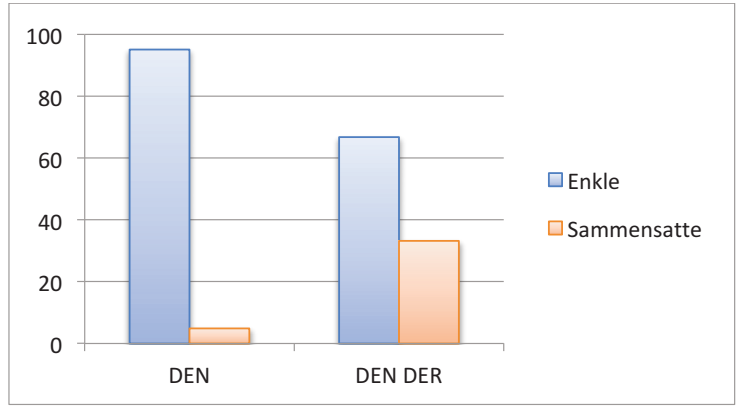

Illustrasjon 4: Enkle vs. sammensatte substantiv $i$ konstruksjoner med enkle og komplekse demonstrativer (i prosent av alle gangene de ulike demonstrativkonstruksjonene forekommer).

\subsection{Demonstrativer og den nedsettende bruksmåten}

Kjennetegnet på referentene til komplekse demonstrativer med foranstilt forsterker er som nevnt i avsnitt 4.3.3 bl.a. at de ikke er tilgjengelige i den umiddelbare konteksten. Generelle referenter som er lett tilgjengelige, som Kongen, sola, skolen, mamma, sønnen din osv. (jf. Givón 2001: 461) er derfor sjelden brukt med demonstrativer. Et unntak er ved nedsettende bruk, særlig av han/hun derre, som Johannessen (2008) kaller psykologisk distale demonstrativer. Disse demonstrativene kan brukes med lett gjenkjennbare/lett tilgjengelige referenter, men da får de en nedsettende eller ironiserende betydning: han derre sønnen din.

En kunne kanskje tenke seg at den nedsettende bruksmåten av persondemonstrativer som han/hun der er en metaforisk ekstensjon av den opprinnelige betydninga av der, altså avstand i rom, men etter mitt syn 
er det mer sannsynlig at den mer generelle bruksmåten til disse demonstrativene (å signalisere lav tilgjengelighet) åpner opp for den nedsettende bruken (jf. avsnitt 4.3.3). Det å signalisere at en referent ikke er lett å hente fram fra minnet, eller ikke er framtredende i samtalen, er en måte å snakke ned noen på. Siden alle demonstrativer har dette potensialet, er i prinsippet alle demonstrativer "psykologisk distale" (jf. f.eks. denne Karlsen, disse kvinnene dine), mens artikler ikke er det, ettersom de signaliserer at noe er velkjent eller lett å identifisere/hente fram. Prepropriale artikler eller navneartikler har derfor en nøytral eller positiv klang (eks. fra NDK: n'far hjalp oss, n’Tore har vert med oss å spille), i motsetning til prepropriale demonstrativer (bu derre dama). Om referenten derimot faktisk er ukjent eller lite framtredende, gir ikke demonstrativer som han derre nødvendigvis noen negativ bieffekt (jf. f.eks.: Har du børt kåseria til han derre Thoresen?). Siden forsterkeren derre gir et entydig signal om at demonstrativet det hører til, nettopp er et demonstrativ og ikke en artikkel, har de også et st $\varnothing$ rre potensial for å bli brukt nedsettende eller ironiserende enn det de enkle han/hun har. Vi kan finne eksempler på humoristisk bruk av demonstrativer med derre i skriftbildet også, f.eks. i overskrifta over det som kanskje er tidenes korteste leserinnlegg, skrevet av Kristian Dragsten:

(11) Den derre rundkjøringa ved Amfi i Svolvar. / Herregud. (Lofotposten,18.2.19) ${ }^{2}$

Av alle gangene bun/han brukes preproprialt eller adnominalt i NDK, er det kun $1 \%$ som brukes med en forsterker (f.eks. han derre Ola). Blant disse konstruksjonene igjen er det forsterkeren derre som er den desidert vanligste, og den videre unders $\varnothing$ kelsen ser derfor kun på denne varianten blant de komplekse prepropriale demonstrativene. Om vi sammenlikner variantene med og uten forsterker i NDK, BigBrother og NoTa, viser en distinktiv kolleksemanalyse at fornavn (som Ola, Kari) er signifikant oftere brukt i konstruksjonen med det enkle prepropriale han/hun. Denne konstruksjonen brukes også ofte med leksemene far, mamma og mor, som ikke forekommer med det komplekse prepropriale han/hun derre i det hele tatt. Det skyldes naturlig nok at at han/hun derre er enty-

2. URL: https://www.lofotposten.no/debatt/svolvar/humor/den-derre-rundkjoringaved-amfi-i-svolvar/o/5-29-461137 (henta 19.12.19) 


\section{URd VindenEs}

dig demonstrativt, mens han/hun ofte har artikkelfunksjon. Det komplekse prepropriale han/hun derre brukes på sin side signifikant oftere med det litt vagere leksemet fyren, som typisk har en ikke-salient referent. Dessuten skiller preproprialt han/hun derre seg distinktivt fra hun/han ved at de typisk brukes med navn på offentlige personer, f.eks. Britney Spears eller Arne Nordheim, som naturlig nok vil være mindre tilgjengelige referenter enn mor eller far. I ill. 5 er de ulike distinktive kolleksemene lista opp.

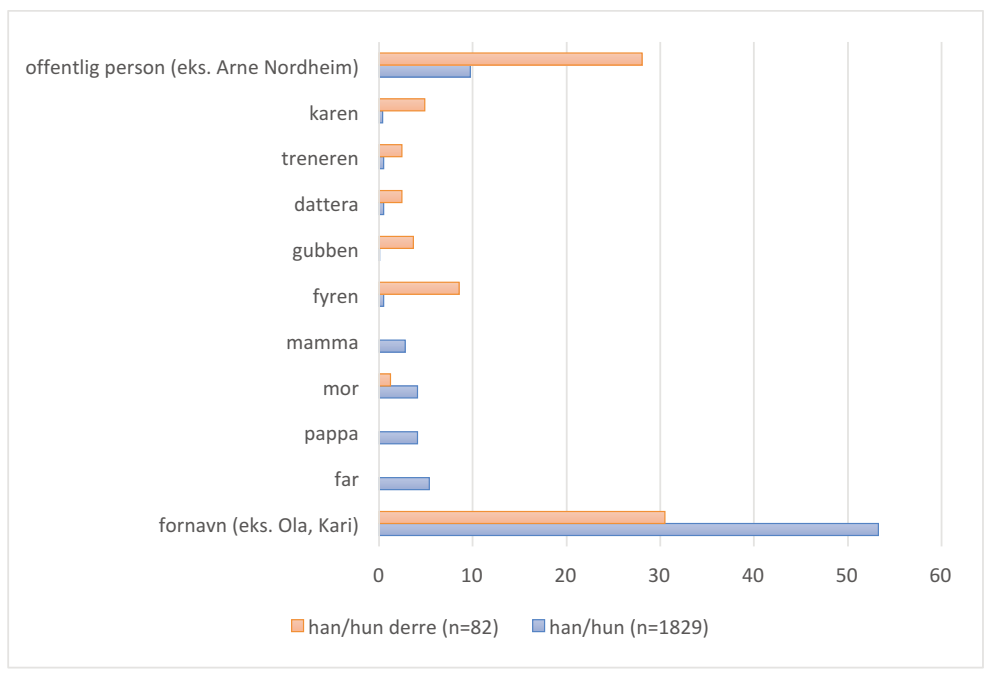

Illustrasjon 5: Kolleksemer som skiller komplekse prepropriale demonstrativer fra enkle prepropriale artikler (forekomsten er oppgitt i prosent av alle forekomstene av henholdsvis han/hun derre og han/hun).

Ifølge Lundeby (1965: 50) hadde også mange av de tidligste eksemplene på bruken av demonstrativet sá med bestemt substantiv i norrønt og mellomnorsk en "klang av forakt". Eksempler som thet skraffuet og thet malet brukt som en negativ omtale av det tyske språket i DN I: 961 fra 1489 viser en tydelig slik bruk (ibid.). Det norrøne $s a ́$ + bestemt substantiv har det til felles med den her/der + bestemt substantiv at den entydig signaliserer demonstrativ funksjon. Dermed kan begge uttrykksmåter brukes for å skape distanse til referenten, som nevnt ofte med en ironisk undertone. Lundeby (1965: 302) hevder videre at bruken av dobbelt bestemthet hos norske forfattere som skreiv dansk på 180o-tallet, skjedde nettopp i 
disse kontekstene, hvor negativt ladde følelser skulle komme til uttrykk (jf. f.eks. uttrykka den akle assessoren, denne stakkars professorposten hos Ibsens Hedda Gabler). Psykologisk distal bruk av demonstrativer er altså på ingen måte noe nytt fenomen.

Alt $\mathrm{i}$ alt viser den distinktive kolleksemanalysen at prepropriale han/hun med forsterkeren derre entydig har demonstrativfunksjon, mens varianten uten forsterker ofte har artikkelfunksjon. Forskjellen på de to funksjonene ser vi bl.a. ved at demonstrativer oftere brukes med navn på offentlige personer som informantene formodentlig ikke kjenner, mens artikler brukes med navn på (antatt) kjentfolk. Prinsippet om at demonstrativer refererer til ikke-saliente, men individuerbare referenter, mens artikler refererer til saliente eller godt kjente referenter, kan brytes for å oppnå en ironiserende effekt.

\subsection{Oppsummering}

Forsterking av demonstrativer kan føre til at nye funksjoner oppstår. I moderne norsk har demonstrativforsterking med her/her og liknende varianter ført til at demonstrativene har fătt et ytterligere formelt skille mellom distal og proksimal distanse, og det gjelder særlig for konstruksjonene med postnominal forsterker (det året her). Men forsterkinga har også gitt opphav til en måte å markere pragmatikaliserte funksjoner på, nemlig markering av spesifikk og privat informasjon, og en implisert "solidaritet" mellom samtalepartnerne. Denne bruken er særlig assosiert med prenominale forsterkere: den derre boka. I avsnitt 5 drøfter jeg hvordan funksjonene og de morfosyntaktiske egenskapene til de komplekse demonstrativene kan ha utvikla seg i norsk.

\section{Historisk utvikling}

\subsection{Ulike varianter av demonstrativforsterkere i norske dialekter}

Det fins en rekke ulike varianter av demonstrativforsterkerne her og der. De kan deles i to hovedgrupper: to- eller flerstava (f.eks. herre, derre) og enstava (her, der). Videre kan de flerstava deles i varianter med og uten $n$, f.eks. herrane mot herre. De enstava og korte variantene brukes over hele landet, samt i skriftlig uformelt bokmål og nynorsk til en viss grad, og det er også disse variantene som brukes med den antatt mest 'grunnleggende' funksjonen, altså den eksoforiske som vi så i eksempel (10): den 


\section{URd VindenEs}

samtalen her. Det at den mest opprinnelige formen er assosiert med den mest opprinnelige deiktiske funksjonen, bør det ikke være behov for å forklare nærmere.

De to- eller flerstava forsterkerne uten $n$, altså herre og derre (herra og derra i noen $\emptyset$ stlandsdialekter, f.eks. i $\emptyset$ stfold), brukes også over hele landet, og disse er forbundet med demperfunksjon og bakgrunnsdeiksis (se avsnitt 2.1). Disse variantene er også tatt inn i Bokmålsordboka ${ }^{3}$ (men ikke i Nynorskordboka), og pussig nok er derre klassifisert som adjektiv, mens herre er blitt et adverb. Det sier kanskje noe om hvor vanskelig det er å avgjøre den grammatiske statusen til disse funksjonsorda, og at ulike redaktører kan ha basert avgjørelsen på ulike egenskaper. De kan nemlig brukes attributivt som adjektiver (den derre bilen), men ikke predikativt eller adverbialt ( ${ }^{*}$ bilen er derre). Begreper som adverb, pronomen og adjektiv er til sjuende og sist bare merkelapper som skal være nyttige for beskrivelse av grammatikken, og dette kartet passer ikke alltid med terrenget.

Blant forsterkervariantene med $n$ i stammen har vi hern, dern, herne, derne, herna, derna, herrane, derrane, herran, derran, m.fl. Norskordbok nevner følgende adverbvarianter i artikkelen om der: der, der, dar, tar, dør, dir, de, de, "sumst med partikkel -a, -an(ne), og -n(e)", dvs. dera, deran(ne), derna og derne. Disse brukes i hver sine dialektområder, men en dialekt som for eksempel har varianten herrane, har i tillegg her og herre. Variantene med $n$ brukes stort sett på Sørvestlandet, i Trøndelag og i NordNorge.

Opphavet til n-variantene er usikkert. En mulighet er at de kommer fra det norrøne hérna (og de distale variantene fra parna), som er danna av adverbet hér og det intensiverende suffikset -na, som var produktivt for flere ordklasser, inkludert adverb, pronomen og verb. Problemet er at overgangen fra -na til -an(e) ikke så lett lar seg spore eller forklare (men et opphav i hérna/parna kan kanskje forklare variantene /he:n/ og /de:n/ på Innherred). En alternativ hypotese til oppkomsten av variantene med $n$ er at de har blitt danna analogisk etter mønster av ord som dettan, dennan, ev. (også) etter mønster av adjektiv med substantivisk bruk, ettersom de i mange dialekter bøyes etter det samme mønsteret: den båten - den kjerra - det huse > den derren - den derra - det derre (jf.

3. URL: https://ordbok.uib.no/perl/ordbok.cgi?OPP $=\&$ bokmaal $=+\&$ ordbok $=$ bokmaal (sist lest 13.1.20) 
den kviten - den kvita - de(t) kvite). Ifølge Norskordbok (bind 1, artikkelen der, s. 1367 ff.) får demonstrativforsterkere ofte bøying som er lik svak adjektivbøying (derre), og videre nevnes den substantiviske bruken med genusbøying i trønderske dialekter (med eller uten et foranstilt den/det), f.eks. maskulinum den'nen, -in eller (den) der'(r)en, -in, mot femininum (den) den'na eller der'-(r)a mot nøytrum (de) den'ne eller der'-(r)e.

Når demonstrativforsterkere brukes adnominalt, står de i den vanlige posisjonen til attributive adjektiv. Det at en del adjektiv kan brukes substantivisk, gir ytterligere en parallell med demonstrativforsterkerne som brukes i pronominelle demonstrativuttrykk (og dessuten med former som dettan, dennan).

I visse dialekter har de komplekse demonstrativene smelta sammen morfologisk, slik at de ikke lenger er analyserbare. I meldalsmålet kan vi finne de distale formene dinna og detta, og de proksimale formene dinner og detter (Stemshaug 1968: 427), som ikke lenger kan deles opp i noe tydelig "demonstrativ + forsterker", ettersom det ikke fins noe demonstrativ dinne i denne dialekten. Dermed fins det altså eksempler på demonstrativer laga gjennom forsterking som ikke lenger er analyserbare, og vi kan ikke lenger snakke om noen separat forsterker.

Ei sammenlikning av korpusene TAUS og NoTa viser at bruken av derre ser ut til å ha $\varnothing \mathrm{kt}$ i oslomålet fra 70-tallet og fram til oo-tallet: fra 65 til $88 \%$ av alle forsterkerne i korpuset. Det er vanlig på tvers av mange språk at det er nettopp den distale varianten og ikke den proksimale som sprer seg i endoforiske brukskontekster (Diessel 1999: 118). Hvorfor det er slik, er vanskelig å si sikkert, men det ser ut til å være en tendens til at "distale" mark $\varnothing$ rer i realiteten er nøytrale og umarkerte fra før, mens de proksimale er de markerte. Når et demonstrativ brukes i en kontekst hvor den deiktiske kontrasten er irrelevant, er det naturlig at det er den umarkerte ("distale") varianten som velges.

\subsection{Morfosyntaktisk utvikling}

Det er som nevnt i avsnitt 2.1 vanskelig å spore utviklinga av komplekse demonstrativer i norsk ettersom de hovedsakelig brukes i muntlig språk til å peke på ting i omgivelsene (eksoforisk bruk). Den eldre historien til de svenske demonstrativene den bär og den där er også "dunkel" (Reinhammar 1975: 57). Likevel er det mulig å finne eksempler både fra norsk og svensk i kilder fra 1400-tallet og utover, særlig med symbolsk eksoforisk funksjon (om utviklinga av pragmatiske bruksmåter, se avsnitt 
5.3). Her vil jeg bruke de historiske belegga som fins i Diplomatarium Norvegicum, KORP og historiske ordbøker (særlig SAOB og Söderwall) for å drøfte mulige utviklingslinjer.

Ifølge SAOB (oppslaget denne här) har det proksimale demonstrativet denne här en lengre historie enn den här og den där. Eksempler fra brev og diplomer i Diplomatarium Norvegicum kan også tyde på at dette er den eldste av de komplekse demonstrativene (som dukker opp i skrift):

(11) erchebespen y Tro(n)-dem skulle haffue verriit y Holland thette her sommer hulchit ieg en-geless troer (DN IX: 679, Vallen, Skåne, 1531)

Dersom det er riktig at det proksimale demonstrativet denne blei forsterka før det distale den, svekker det forklaringer på forsterking som antar at grammatikalisering av demonstrativet er en bakenforliggende årsak (ettersom denne i mindre grad er grammatikalisert enn den). En hypotese som er løfta fram av SAOB (ibid.), er at den här har opphav i denna här, med bortfall av den trykklette vokalen i andrestavelsen. En slik apokopering fører til lydlig sammenfall av denne og den, men med tillegget av här/där kan den deiktiske kontrasten likevel opprettholdes. Likevel er det vanskelig å støtte denne hypotesen all den tid denne og denne her fortsatt er i bruk (om enn mindre i svensk enn i norsk). Reinhammar (1975: 58) er også kritisk til hypotesen i SAOB siden de kun st $\varnothing$ tter seg til ett enkelt eksempel.

Hvorvidt forsterkingsprosessen begynte gjennom et tillegg av foranstilte eller etterstilte forsterkere, er også vanskelig å si helt sikkert. Det er flere muligheter: Determinativt denne (ev. den) kan ha blitt forsterka via kontekster der en ellers også kan legge til et foranstilt adjektiv eller annet attributt (som thenne forne skick, DN XII: 649, 1552, eller thette mijtt obne breff, DN VI: 761, 1545), eller via kontekster der et adverbial står som etterstilt tillegg til substantivet (som thette breffepther biscopen, DN XVI: 652, 1557).

De to utviklingene skissert over kan ha skjedd uavhengig av hverandre, og i så fall er det rimelig å anta at varianten med foranstilt her/der er den eldste varianten. For det første ser varianten med etterstilt forsterker (den NP her/der) ut til å ha en tydeligere eksoforisk og kontrastiv bruk (altså en "primær" funksjon som ligger nærmere de adverbiale her/der), mens den her/der NP ser i moderne norsk ut til å ha mer pragmatikaliserte funksjoner (jf. avsnitt 2.1 og 4.3). For det andre gir datama- 
terialet fra tidlig moderne norsk og svensk et klart inntrykk av at den sistnevnte konstruksjonen er mer vanlig: thette her kyøpph (DN XIV: 824, 1546), thette her sommer (DN IX: 679, 1531), Thenne her schriffwilse (SAOB, denne här, 1547) (se også avsnitt 2.1 for flere slike eksempler). Konstruksjonen den(ne) NP her/der er utvilsomt vanskeligere å finne i så tidlige tekster, dessuten er den også helt marginal i svensk. Det er vanskelig å si nøyaktig når konstruksjonen dukka opp i norsk, men den er som sagt vanskelig å oppdrive i kildematerialet fra 1500-tallet (eller før), noe som kan tyde på at den $N$ her/der er relativt ny i norsk.

Overgangen fra attributiv til pronominal bruk er ikke like problematisk å forklare, ettersom det kan skje via konstruksjoner med underforstått substantiv. Slik bruk av den(ne) her/der fins det flere eksempler på i det eldre materialet:

(12) then tridie saak er tesse häre (Söderwall, oppslaget här, seint 1400tall/tidlig 1500-tall. Eksempelet er fra Svenska Medeltidens Rim-Krönikor, bind 1 )

Som det kommer fram i de eksemplene som er nevnt her, var det tidligere tilsynelatende utelukkende bruk av ubestemt form på substantivet $\mathrm{i}$ konstruksjoner med den(ne) her/der N (thenne her tiid, thette her sommer osv.). I moderne norsk framstår nok bruken av ubestemt form i en slik kontekst ganske arkaisk og/eller dansk-klingende, og det vanligste i norsk er uten tvil bestemt form (denne her tida). I tidligere svensk har bruken av bestemt og ubestemt form vært mer vaklende, og en finner både eldre eksempler som Dhenna här hårdha wintheren (SAOB, denne här; 1690) og thenne bär stund (ibid., ca. 1580). I moderne svensk er også bestemt form så å si enerådende i denne konstruksjonen, som i norsk. Det fins ifølge Lundeby (1965: 43 ff.) eksempler på bruk av dobbelt bestemthet i substantivfraser med demonstrativ i norrønt, gammalsvensk og mellomnorsk, særlig der substantivet følges av en relativsetning (sa dommaren er ..., then hesten som ..., ibid. s. 65). Slike konstruksjoner må ifølge Lundeby ha vært i bruk seinest fra 1200-tallet, men de hadde sannsynligvis et talemålspreg, siden en overvekt av eksemplene fins i talegjengivelser. Hvorfor bruken av ubestemte substantiv ser ut å være vanligere sammen med komplekse demonstrativer i mellomnorsk enn de bestemte, er uklart. Kanskje kan det forklares så enkelt som at bruken av enkelt bestemthet uansett var vanligere på dette tidspunktet, i hvert fall i skrift. 


\section{URD VINDENES}

Oppsummeringsvis er det mye som tyder på at det var det proksimale demonstrativet som blei forsterka først. Sannsynligvis er konstruksjonen med foranstilt forsterker (denne her/der N) eldre enn den med etterstilt forsterker, og den førstnevnte er også mer utbredt i hele det skandinaviske området. Tidligere var det hovedsakelig brukt ubestemt substantiv sammen med disse demonstrativene, men når dobbelt bestemthet har spredd seg og overtatt i norsk (og i stor grad i svensk), har dette også skjedd i demonstrativkonstruksjoner.

\subsection{Utvikling av den deiktiske funksjonen}

I de tidligste eksemplene jeg har funnet i norsk og svensk, er den deiktiske referansen symbolsk eksoforisk. Eventuelle gestbaserte eksoforiske referanser måtte vært brukt i sitater, men også i slike kontekster har det vært vanskelig å oppdrive eksempler (jf. avsnitt 2.1). Likevel er det rimelig å anta at den gestbaserte eksoforiske bruken er den primære, som også SAOB antar for svensk ("1) med syftning på ngt i rummet", oppslaget denne här):

(13) Om j thenne här Gatun gå (SAOB, oppslaget denne här, sitatet er fra Brasck: Filius prodigus, seu imperitus peregrinans, 1645)

I moderne norsk er det noe overraskende den bakgrunnsdeiktiske funksjonen (som i Husker du den derre filmen?) som ser ut til å være distinktiv for de komplekse demonstrativene med foranstilt forsterker (se avsnitt 4.3). Det er overraskende at et nytt demonstrativ er forbundet med en såpass "videre"-grammatikalisert funksjon, ettersom konteksten for fornying av demonstrativer er eksoforisk peking. I andre språk, f.eks. de romanske, ser vi at de nye, komplekse demonstrativene brukes med eksoforisk funksjon (f.eks. fransk cette), mens det som stammer direkte fra demonstrativet i latin, brukes med grammatikalisert funksjon (bestemt artikkel) i moderne fransk (le, la).

Man skulle altså forvente at det var de enkle demonstrativene som blei brukt oftest med bakgrunnsdeiktisk funksjon, mens de komplekse demonstrativene hadde eksoforisk funksjon, og ikke omvendt. Grunnen til at det har blitt slik i norsk, kan være at vi har to ulike familier av komplekse demonstrativer, nemlig den med foranstilte og den med etterstilte forsterkere (hvorav den siste antakelig er nyere). Det er hovedsakelig varianten med foranstilte forsterkere (den derre fyren) som brukes med en- 
doforisk funksjon, mens varianten med etterstilte forsterkere (den fyren der) er mer assosiert med den eksoforiske bruken (jf. avsnitt 4.3.2). Det ser vi ved at forsterkeren $i$ den sistnevnte varianten har opprettholdt kontrasten mellom proksimal og distal betydning, mens foranstilte forsterkere gjerne har mer bleika distansebetydning.

Siden de to ulike variantene av komplekse demonstrativer ikke bare konkurrerer paradigmatisk med de enkle demonstrativene, men også med hverandre, har de to variantene fătt hver sin nisje: Demonstrativer med etterstilt forsterker brukes oftere i eksoforiske kontekster, mens demonstrativer med foranstilt forsterker brukes oftere i endoforiske kontekster. Enkle demonstrativer - den eldste konstruksjonen - brukes på sin side i alle kontekstene, men er den eneste som grenser mot enda mer grammatikaliserte funksjoner som artikkelfunksjon eller personlig pronomen.

\subsection{Videre grammatikalisering av den der}

I avsnitt 4.2 så vi at komplekse demonstrativer er særlig bruksfrekvente i nordnorsk. Dette kan både være et resultat av, og en videre pådriver for, at de komplekse demonstrativene blir mer grammatikalisert. I deler av korpusmaterialet fra NDK ser det ut til at komplekse demonstrativer som den $\operatorname{der}(r e)$ har fått nye funksjoner i tillegg til de eksoforiske, anaforiske og bakgrunnsdeiktiske - de kan nemlig brukes som en slags bestemt artikkel og som personlig pronomen:

(14) Vil man gjøre noe annet, så kan man jo sette seg på det der flyet og dra sørover viss det er så mye mer eksklusivt å b- være sørpå, liksom (NDK, Troms $\varnothing$ )

(15) så han fortsatte bortover den der gata (Sørreisa, fra Målførearkivet)

I (14) ser vi at det der brukes med et substantiv som har generisk og lett tilgjengelig referent, et fly. At den der kan ha artikkelaktig funksjon, ser vi også i (15), der gata det er snakk om, er nevnt tidligere i samtalen. Når en referent fortsatt er i fokus i samtalen, er ikke funksjonen til den der å aktivere, peke ut eller signalisere at en referent må hentes fram i minnet, men å markere bestemthet.

I nord-skandinaviske dialekter (og dessuten i älvdalsk, se Dahl 2015: 83) ser det ut til å være en tendens til at den bestemte etterhengte artikkelen sprer seg til ikke-bestemte kontekster (Dahl 2003: 171 ff.), altså at 


\section{URd VindenEs}

den mister bestemthetsfunksjonen. Jahr og Skare (1996: 213) har pekt på at den etterhengte artikkelen i visse dialekter kan ha ubestemt, men spesifikk referanse, som i en knausen. Dette kan ifølge Jahr og Skare være et lån fra finsk eller samisk, men det er usikkert. Ifølge Lundeby (1965: 227-228) fins dette fenomenet også i noen vestnorske dialekter, og han nevner eksempler som kvar dagen og her ein dagen, og det svekker hypotesen om at det er kontaktfenomen fra finsk eller samisk. Uansett har dette grammatiske mønsteret vært stigmatisert, og i dag finner en det stort sett bare i faste uttrykk. Dahl (2003) peker på flere grammatikaliseringsprosesser som kan føye seg inn i denne generelle tendensen, altså at bestemte artikler (foranstilte og etterstilte) grammatikaliseres videre til å bli generelle genus- eller bøyingsklassemark $\varnothing$ rer. Grammatikaliseringa av den der fra demonstrativ til bestemthetsmark $\varnothing \mathrm{r}$ kan også føye seg inn i dette endringsmønsteret, men et steg "lenger oppe" på grammatikaliseringsstien (eng. grammaticalization cline). Dahls grammatikaliseringssti for demonstrativer kan bygges ut slik, på bakgrunn av den skandinaviske evidensen presentert her:

Eksoforisk demonstrativ $>$ endoforisk demonstrativ $>$ anaforisk/ diskursdeiktisk/ bakgrunnsdeiktisk demonstrativ > bestemt artikkel > type-identifiserbar (generisk) genusmark $\varnothing \mathrm{r}$

\section{En bruksbasert tilnærming til forsterkingssykluser}

\subsection{Forsterking i emfatiske kontekster}

Demonstrativforsterking er en prosess som skjer uavhengig av grammatikalisering av enkle demonstrativer. Jeg finner st $\varnothing$ tte for argumentene i litteratur om negasjonsforsterking. I nyere forskning har det vært argumentert for at forsterking av nektingsuttrykk (som ne ... pas i fransk) skjer i såkalt emfatiske brukskontekster (van der Auwera 2009: 53; Mosegaard Hansen 2011: 573; Willis et al. 2013: 18). Miestamo (2005, s. 210) påpeker at forsterking av negasjonsmark $\varnothing$ rer skjer i kontekster der nektinga allerede er eksplisitt uttrykt. Det er kanskje nærliggende å tenke at det er større "behov" for forsterking ved implisert nekting (for eksempel i retoriske spørsmål som Hvem bryr seg?, hvor implikaturen er 'ingen bryr seg'), siden den kan være vanskeligere å oppfatte, men det er altså ikke på grunn av manglende styrke at negasjonsmarkører får forsterking. 
Termene emfase og emfatisk har så langt i artikkelen vært brukt uten en klar definisjon. De kan være intuitivt greie å forstå, men lingvister kan likevel ha ulike tolkninger av dem. Innen forsking på negasjonsforsterking er gjerne minimerende uttrykk som (ikke) en døyt og (ikke) en dritt trukket fram eksempler på emfatiske forsterkere. Blaxter og Willis (2018), som baserer seg på Israel (2011), påpeker at slike forsterkeruttrykk er skalare (framkaller alternativer på en skala, og er mer eller mindre "sterke"), samt at de har en høy informasjonsverdi, og på bakgrunn av dette blir emfase definert slik: "Emphasis involves a speaker expressing the attitude that the informative strength of their proposition is high" (ibid., s. 425). Et sentralt poeng er at de emfatiske negasjonsforsterkerne framkaller alternative proposisjoner på en skala for mottakeren (f.eks. jeg spiste ikke en baguette vs. jeg spiste ikke så mye som en smule). Emfatiske demonstrativforsterkere har noe av den samme funksjonen i de eksoforiske kontekstene, hvor forsterking først skjer: den koppen der er en tydelig kontrast til den(ne) koppen her. Kontekster der avsenderen vil framheve en slik kontrast eller noe antatt uventa, kan kalles emfatiske kontekster. Når avsenderen vil framheve dette enda tydeligere med trykk, legges normalt trykket på forsterkeren, ikke på negasjonen eller på demonstrativet (gi meg den der, jeg skjønte ikke et kvekk).

Det er ikke noe problem å forsterke et negerende eller demonstrativt uttrykk kun ved hjelp av trykk (jeg vil ikke lese mer, denne varfin!). Grunnen til at andre elementer rekrutteres som forsterkere, kan være at de uansett ofte vil forekomme i emfatiske kontekster. Israel (2011: 110 f.) har foreslått at bruken av negasjonsforsterkere kan skyldes en form for høflighetsstrategi der taleren $\varnothing$ nsker å $\varnothing$ ke mottakerens interesse ved å gjøre uttrykket mer overraskende (eller i tilfellet demonstrativforsterking - kontrastfullt). Ved emfatisk nekting vil det ofte være generaliserende eller minimerende uttrykk til stede, og ved eksoforisk deiksis vil det ofte være et lokasjonsuttrykk.

Når ord ofte kollokerer, som demonstrativer eller negasjoner og forsterkere kan gjøre, kan de bli utsatt for blokkdanning (på engelsk chunking, definert av Bybee 2010: 7 slik: "the process by which sequences of units that are used together cohere to form more complex units"). Blokkdanning innebærer ikke nødvendigvis lydlig koalesens av kollokasjonen (som i det derre $>$ derre), men det innebærer alltid en semantisk reanalyse av de opprinnelig sjølstendige elementene, slik at de oppfattes som ett sammenhengende uttrykk. Det blir synlig når f.eks. den der ikke lenger 


\section{URD VINDENES}

har noen spatial deiktisk funksjon (som i den der ideen din). Som en del av blokkdanninga kan altså forsterkerelementet miste sin opprinnelige betydning: Det franske pas betyr ikke lenger 'skritt' i uttrykket ne ... pas, og det norrøne $e k k i$ betyr ikke lenger 'noen ting som helst' i uttrykket ne ... ekki - de har nektelsesbetydning, men i første omgang kun sammen med det opprinnelige nektingsuttrykket. Slik er det også for demonstrativer: der har ikke lenger stedsbetydning i uttrykket den der sangen, men har endoforisk deiktisk funksjon sammen med den.

Det forsterka uttrykket, altså demonstrativ eller negasjon pluss forsterker, kan gjennomgå semantisk reduksjon over tid, ved at det emfatiske uttrykket blir reanalysert som nøytralt/ikke-emfatisk. Dette er en vanlig mekanisme i grammatikaliseringsprosesser, som ofte også innebærer fonetisk reduksjon (som gjerne går utover det gamle demonstrativet/negasjonen, og ikke forsterkeren, jf. det franske ne $V$ pas, hvor ne ofte er svekka i muntlig fransk). Det samme ser vi i de komplekse demonstrativene i norsk, som i den der ideen, der hele det komplekse demonstrativet har fått redusert eksoforisk betydning.

Utviklinga av demonstrativ- og negasjonsforsterkere er typiske eksempler på grammatikalisering, fordi disse elementene taper autonomi (jf. Lehmann 2015: 130): De desemantiseres (får mer abstrakt betydningsinnhold), mister syntaktisk frihet, og de kan smelte sammen med andre elementer (kalt koalesens). Disse prosessene ser vi både i utviklinga av negasjonsforsterkere som det franske pas eller det norrøne ekki (som har opphav i negasjonen ne pluss forsterkeren eigi/ekki 'noen ting som helst'), og i utviklinga av nye demonstrativer som det trønderske herre/derre. Men den totale fornyingsprosessen, dvs. overgangen fra demonstrativet den til derre, eller fra ne til ekki, er som nevnt i avsnitt $\mathbf{2 . 2}$ en annen type endring enn grammatikalisering - det er fornying eller renovasjon. Forsterkerorda i slike fornyingsprosesser har nok gjennomgått grammatikalisering, men det er bare en del av forsterkingssyklusen.

Historia om forsterking av demonstrativer med ecce i romanske språk blir gjerne forklart med at demonstrativene hadde behov for å fornyes, siden hoc og iste var blitt grammatikalisert til artikler (se f.eks. van Gelderen 2011, 220-221). Om et forsterkerelement som ecce 'se' blir brukt i faktisk tale, trenger ikke det bety at demonstrativet ikke hadde vært 'tilstrekkelig' aleine for å peke ut noe (jf. avsnitt 2.2). Faktisk språkbruk inneholder mye redundans, og ofte kommer de ulike delene av slike doble uttrykk fra strata eller lag av forskjellige grammatikaliseringsprosesser. 
De eldste strataene er gjerne obligatoriske (obligatorifisering er et kjennetegn på langtkommen grammatikalisering - altså på grammatikk), mens nyere ikke er det. Et eksempel på slike strata er uttrykk for temporal deiksis gjennom både verbbøying og tidsadverbial (Jeg leste i går). Fortidsformen av verbet er obligatorisk (*jeglese i går), og den er også den eldste og mest generelle måten å uttrykke fortid på, mens $i$ går er både spesifikt og ikke-obligatorisk.

Reanalysen av ord som ecce 'se' eller der som en forsterker kan som nevnt skje om ordet brukes hyppig sammen med demonstrativer, slik at fraser som ecce ille 'se den' eller den der produseres mer automatisk. $\mathrm{Mu}$ lige overgangskontekster for den der (altså kontekster hvor tolkinga er tvetydig, og reanalyse er mulig), kan være uttrykk hvor spesifikke stedsadverb står adnominalt (den båten ved kaia vs. den båten der) eller som tillegg til et demonstrativpronomen: Se på den oppå hylla vs. Se på den der (jf. avsnitt 5.2). Det at et uttrykk allerede har litt mer generell betydning (jf. der med oppå bylla), фker selvfølgelig det potensielle antallet brukskontekster, og dermed $\varnothing$ ker også sannsynligheten for reanalyse og blokkdanning. Når ecce i vulgærlatin eller der i norsk først har mista mye av den tidligere betydninga fordi de tolkes som en del av demonstrativuttrykket, kan de spre seg til nye brukskontekster som ikke var mulig før, f.eks. kontekster der man ikke nødvendigvis kan se objektet som utpekes, som ved diskursdeiksis (Hør på det her).

I dette avsnittet har jeg argumentert for at den mulige blokkdanninga og reanalysen av den der og liknende komplekse demonstrativer skjer fordi de forekommer relativt hyppig sammen i emfatiske kontekster. En slik tilnærming til forsterkingssykluser ser altså bort fra eventuell grammatikalisering eller svekking av et tidligere demonstrativ (som den, ille, hoc osv.). I neste avsnitt drøfter jeg hvorfor slik grammatikalisering likevel kan henge sammen med forsterkingssyklusen, via bieffektene av paradigmatisk konkurranse mellom nye og gamle demonstrativer.

\subsection{Konkurranse om funksjonelle nisjer i syklisk endring}

I avsnitt 6.1 har jeg argumentert for at demonstrativer ikke blir forsterka som et resultat av at enkle demonstrativer er grammatikalisert, til tross for at resultatet av slike endringer kan være at gamle demonstrativer blir erstatta av nye (og komplekse) demonstrativer. Et alternativt syn på demonstrativforsterking er at demonstrativsystemet endrer seg syklisk. I et slikt syn tar man utgangspunkt i funksjonelle nisjer (se Aronoff 2016), 


\section{URD VINDENES}

snarere enn formen. Et eksempel på en nisje er 'eksoforisk deiksis', som ifølge Diessel (1999) mest sannsynlig er dekket i alle språk. Grunnen til at den er universell, er at det å rette oppmerksomheten om noe felles er en grunnleggende del av den muntlige kommunikasjonen (se Diessel 2006 om "joint attention"). Vi bruker de ressursene vi har i språket for å oppnå dette, ofte sammen med pekegester. Men i tillegg til å bruke demonstrativer, bruker vi som nevnt $i$ avsnitt 6.1 tilleggsord $i$ disse kontekstene, som ord for 'se', 'her', 'der', som kan smelte sammen med demonstrativer over tid pga. frekvent bruk. Da vil den funksjonelle nisjen fylles av en $n y$ form, i tillegg til den gamle. Eksempler på dette kan være den der og den, som begge kan ha den samme eksoforiske funksjonen (fylle den samme nisjen), og som dermed er i paradigmatisk konkurranse med hverandre. Forskjellen på de to demonstrativene er at det enkle den er assosiert med flere andre funksjoner enn bare den eksoforiske - for eksempel kan det brukes som foranstilt bestemt artikkel i fraser som den norske regjeringa. Det komplekse den der er neppe like frekvent som den, men det er i høyere grad forbundet med eksoforisk bruk, nettopp fordi det ikke er fordelt over like mange nisjer. Over tid kan det føre til at det komplekse og nye demonstrativet "skyver" det gamle nedover grammatikaliseringsstien. På den måten kan paradigmatisk konkurranse være en katalysator for grammatikalisering, uten å være ikke en direkte årsak.

Hva er det som trigger grammatikaliseringa av enkle demonstrativer til f.eks. artikler? Ifølge Boye og Harder (2012) er syntagmatisk konkurranse en viktig årsak til grammatikalisering. Syntagmatisk konkurranse vil si at de ulike elementene i ei ytring konkurrerer om å være prominente eller framtredende. De som taper konkurransen om diskursprominens, faller så å si i "bakgrunnen" og er mer utsatt for å bli grammatikalisert. Typiske eksempler på dette er preposisjoner, som er mindre prominente enn utfyllingene sine ( $p a ̊$ stranda), eller foranstilte bestemte artikler, som "taper konkurransen" med substantiv (den fine jakka). Diskursprominens kan måles på ulike måter, bl.a. om det er mulig å fokusere uttrykket ved å legge trykk på det. Syntagmatisk konkurranse kan forårsake grammatikalisering av demonstrativer, mens paradigmatisk konkurranse kan katalysere pågående grammatikalisering fordi variantene differensieres.

Lundeby (1965) trekker fram syntagmatisk konkurranse (samt bruksfrekvens-effekter) som sentral for utviklinga av den etterhengte bestemte artikkelen: 
... slik overdrivelse [av bruken av forsterkende elementer, dvs. av demonstrativpronomen] kan føre til det dem. pron. stadig oftere blir lagt til subst., inntil det under visse syntaktiske og semantiske vilkår blir substantivets faste følgesvenn. Dermed har pronomenet gått over til artikkel. (Lundeby 1965: 11)

Det er etter all sannsynlighet samme mekanisme som har spilt inn når det enkle demonstrativet den har mista deiktisk betydning i en del bruksmåter (som med adjektiv: den fine jakka). Grammatikalisering av demonstrativer (i visse kontekster) kan naturligvis skje uten at det har oppstått et nytt, forsterka demonstrativ først. Men hovedpoenget her er at grammatikalisering ikke er en forutsetning for forsterking. Hadde det vært det, ville vi kanskje venta at den etterstilte artikkelen -inn i norrønt også hadde behov for en forsterker, men det skjedde ikke. Derimot splitta (b)inn seg i to funksjoner i hver sine kontekster: Den nye artikkelfunksjonen og den gamle demonstrativfunksjonen, som besto en stund til.

\subsection{Oppsummering}

I dette avsnittet har jeg lagt fram et forslag til en bruksbasert tilnærming til forsterkingssykluser. Tradisjonelle formbaserte modeller for grammatikalisering kan som nevnt i avsnitt 2.1 og 6.1 ikke gjøre rede for alle delene av fornyingsprosessen der demonstrativer eller negasjoner blir fornya gjennom forsterkning, men de kan gjøre rede for enkeltvise steg i utviklinga. Grammatikaliseringa av enkle demonstrativer som den, det latinske ille mfl. (og også av forsterkerord som der og ecce) kan anses som et resultat av en form for syntagmatisk konkurranse (jf. Boye og Harders 2012 bruksbaserte teori om grammatisk status). Ved også å se på mulige mekanismer i paradigmatisk konkurranse (Aronoff 2016), i tillegg til den syntagmatiske, kan st $\varnothing$ rre deler av forsterkingssyklusen belyses.

Konkurranse mellom to eller flere uttrykk om en nisje (f.eks. den vs. den der for påpekende funksjon) oppstår etter all sannsynlighet pga. at bestemte ord tiltrekkes bestemte kontekster (f.eks. deiktiske kontekster), og at det på den måten dannes nye demonstrativer gjennom blokkdanning. Denne tiltrekninga kan i seg sjøl neppe kalles grammatikalisering. Likevel fins det mange eksempler på at det ene av de to konkurrerende uttrykka gjennomgår en grammatikaliseringsprosess. En slik grammatikalisering er ikke en forutsetning for at en forsterker skal bli rekruttert, men kan framskyndes som en følge av forsterkinga, når det oppstår to uttrykk som konkurrerer paradigmatisk med hverandre. 


\section{URD VINDENES}

Ulike teoretiske tilnærminger kan bidra til å belyse ulike sider av spesifikke språklige fenomener. En bruksbasert tilnærming til demonstrativfornying skiller seg hovedsakelig fra mer formelle tilnærminger (f.eks. den presentert av van Gelderen 2011) ved at den legger noe st $\varnothing$ rre vekt på effektene som bruksmønstre (f.eks. valget av visse leksem i emfatiske kontekster) har på endringene. Dette bidrar til å belyse spørsmålet om hvilke ord som inngår som i forsterkingssykluser. Et annet skille mellom bruksbaserte og generative tilnærminger er at førstnevnte i større grad ser synkrone språksystemer og diakrone prosesser under ett. Paradigmatisk konkurranse mellom to varianter av demonstrativer er et eksempel på en prosess som både må sies å være synkron og diakron, og som påvirker utviklinga i en forsterkingssyklus. De ulike tilnærmingene er ikke motsetninger, men kan utfylle hverandre. De generative tilnærmingene har bidratt med å formalisere endringene som skjer i en syklus, men målet her har vært å drøfte hvordan variasjonen (og dermed den paradigmatiske konkurransen) har oppstått.

\section{Avslutning}

I denne artikkelen har jeg presentert en korpusbasert studie av komplekse demonstrativer i norsk, og mulige motivasjoner bak forsterkingsprosessen som gir opphav til slike demonstrativer. Data fra talespråkskorpus belyser funksjonene komplekse demonstrativer har fătt i moderne norsk: markering av spesifikk og privat informasjon, entydig deiktisk funksjon (dvs. ikke artikkel-funksjon, som igjen kan brukes for å implisere psykologisk distanse), og et signal om et bånd mellom samtalepartnerne. Når flere nærsynonyme konstruksjoner, som den $N$, den $\operatorname{der} N$ og den $N$ der, fins, konkurrerer de paradigmatisk, eller de konkurrerer om en funksjonell nisje. Resultatet av en slik nisjekonkurranse kan være at den ene konstruksjonen skyves framover i grammatikaliseringsstien og at den andre overtar den gamle funksjonen (da er det snakk om en reell fornying), eller at de ulike konstruksjonene spesialiserer seg $\mathrm{i}$ hver sin funksjon. I norsk ser det ut til at de komplekse demonstrativene med etterstilt forsterker hovedsakelig har spesialisert seg som mark $\emptyset$ rer for eksoforisk (proksimal, distal) referanse, mens varianten med foranstilt forsterker i stor grad har mista den deiktiske kontrasten, og brukes som mark $\varnothing \mathrm{r}$ for bakgrunnsdeiksis. 
I litteraturen har enkelte pekt på grammatikaliseringa eller "svekkinga" av demonstrativer som en årsak til at de tiltrekker seg en forsterker (f.eks. van Gelderen 2011). Siden demonstrativer er så grunnleggende og sentrale i menneskelig språk, bl.a. for å oppnå felles oppmerksomhet (Diessel 2006), er det lite sannsynlig at forsterkinga skjer etter en svekkelse. I denne artikkelen har jeg argumentert for at demonstrativforsterkinga skjer i såkalte emfatiske kontekster (slik forsterking også er beskrevet i negasjonssykluser), og at ei eventuell svekking av det gamle demonstrativet skjer pga. en påfølgende paradigmatisk konkurranse mellom det nye og det gamle demonstrativet. Forsterking kan katalysere grammatikalisering, men grammatikalisering kan neppe utløse forsterking. Sameksistensen av nye og gamle demonstrativer i norsk, som begge kan ha påpekende funksjon, styrker denne hypotesen.

\section{Bibliografi}

Aronoff, Mark. 2016. Competition and the lexicon. I: Livelli di Analisie fenomeni di interfaccia. Atti del XLVII congresso internazionale della società di linguistica Italiana, red. Annibale Elia, Claudio Iacobini og Miriam Voghera, 39-52. Roma: Bulzoni.

van der Auwera, Johan. 2009. The Jespersen cycles. I: Cyclical change, red. Elly van Gelderen, 35-71. Amsterdam/Philadelphia: John Benjamins.

Baayen, R. Harald. 2009. Corpus linguistics in morphology: morphological productivity. Corpus linguistics. An international handbook, red. Anke Lüdeling og Merja Kytö, 900-919. Berlin: De Gruyter Mouton.

Barðdal, Jóhanna. 2008. Productivity: Evidence from case and argument structure in Icelandic. Amsterdam/Philadelphia: John Benjamins.

Blaxter, Tam og David Willis. 2018. Pragmatic differentiation of negative markers in the early stages of Jespersen's cycle in North Germanic. Diachronica, 35 (4): 451-486.

Borin, Lars, Markus Forsberg og Johan Roxendal. 2012: Korp - the corpus infrastructure of Språkbanken. Proceedings of LREC 2012. Istanbul: ELRA: 474-478.

Boye, Kasper og Peter Harder. 2012. A usage-based theory of grammatical status and grammaticalization. Language 88(1): 1-44. 
Bybee, Joan L. 2010. Language, usage and cognition. Cambridge: Cambridge University Press.

Bybee, Joan L., Revere Perkins og William Pagliuca. 1994. The Evolution of Grammar: Tense, Aspect, and Modality in the Languages of the World. Chicago/London: The University of Chicago Press.

Clark, Eve V. 2009. First language acquisition. Cambridge: Cambridge University Press.

Dahl, Östen. 1979. Typology of sentence negation. Linguistics, 17(1-2): 79-106.

-2003. Definite articles in Scandinavian: Competing grammaticalization processes in standard and non-standard varieties. I: Dialectology meets typology: Dialect grammar from a cross-linguistic perspective, red. Bernd Kortmann, 147-180. Berlin: Walter de Gruyter.

- 2015. Grammaticalization in the North: Noun phrase morphosyntax in Scandinavian vernaculars. Berlin: Language Science Press.

Diessel, Holger. 1999. Demonstratives: Form, Function and Grammaticalization. Amsterdam/Philadelphia: John Benjamins.

-2006. Demonstratives, joint attention, and the emergence of grammar. Cognitive Linguistics, 17(4): 463-489.

Dixon, Robert M. W. 2003. Demonstratives: A cross-linguistic typology. Studies in Language, 27(1): 61-112.

Dyvik, Helge. 1979. Omkring fremveksten av artiklene i norsk. Språklig markering av referensielle forutsetninger. Maal og Minne, 1979(1): $40-78$.

Enger, Hans-Olav og Tore Nesset. 2011. Constraints on Diachronic Development: The Animacy Hierarchy and the Relevance Constraint. STUF-Language Typology and Universals 64(3): 193-212.

Faarlund, Jan Terje, Svein Lie og Kjell Ivar Vannebo. 1997. Norsk referansegrammatikk. Oslo: Universitetsforlaget.

van Gelderen, Elly. 2011. The linguistic cycle: Language change and the language faculty. Oxford: Oxford University Press.

Givón, Talmy. 2001. Syntax: An introduction, vol. 1. Amsterdam/Philadelphia: John Benjamins.

Greenberg, Joseph H. 1978. How does a language acquire gender markers? I: Universals of human language. Volume 3: Word structure, red. Joseph H. Greenberg, Charles A. Ferguson og Edith A. Moravcsik, 47-82. Stanford: Stanford University Press. 
Gries, Stefan T. 2010. Behavioral profiles: A fine-grained and quantitative approach in corpus-based lexical semantics. The Mental Lexicon, 5(3), 323-346.

Gries, Stefan T. og Anatol Stefanowitsch. 2004. Extending Collostructional Analysis: A Corpus-Based Perspective on Alternations. International Journal of Corpus Linguistics, 9(1), 97-129.

Hansen, Maj-Britt Mosegaard. 2011. Negative cycles and grammaticalization. I: The Oxford Handbook of Grammaticalization, red. Heiko Narrog og Bernd Heine, 570-579. Oxford: Oxford University Press. Haspelmath, Martin. 2004. On directionality in language change with particular reference to grammaticalization. I: $U_{p}$ and down the cline. The nature of grammaticalization, red. Olga Fischer, Muriel Norde og Harry Perridon, 17-44. Amsterdam/Philadelphia: John Benjamins.

Himmelmann, Nikolaus P. 1996. Demonstratives in narrative discourse: A taxonomy of universal uses. I: Studies in Anaphora, red. Barbara A. Fox, 205-254. Amsterdam/Philadelphia: John Benjamins.

- 2004. Lexicalization and Grammaticalization: Opposite or orthogonal? I: What Makes Grammaticalization?: A Look from Its Fringes and Its Components, red. Walter Bisang, Nikolaus P. Himmelmann og Björn Wiemer, 21-42. Berlin/New York: Mouton de Gruyter.

Israel, Michael. 2011. The grammar of polarity: Pragmatics, sensitivity, and the logic of scales. Cambridge: Cambridge University Press.

Jahr, Ernst Håkon og Olav Skare. 1996. Nordnorske dialektar. Oslo: Novus.

Jespersen, Otto 1917. Negation in English and other Languages. København: A. F. Høst \& Søn.

Johannessen, Janne Bondi. 2006. Just any pronoun anywhere? Pronouns and 'new' demonstratives in Norwegian. I: A Festschrift for Kjell Johan Sabø - in partial fulfilment of the requirements for the celebration on his 5oth birthday, red. Torgrim Solstad, Atle Grønn og Dag Haug, 91106. Oslo: Unipub.

- 2008. The pronominal psychological demonstrative in Scandinavian: Its syntax, semantics and pragmatics. Nordic Journal of Linguistics 31(2). 161-192.

- 2012. Han professoren og sånn festskrift - om modale determinativer. I: Grammatikk, bruk og norm. Festskrift til Svein Lie på 7o-årsdagen 15. april 2012, red. Hans-Olav Enger, Jan Terje Faarlund og Kjell Ivar Vannebo, 151-172. Oslo: Novus. 


\section{URd VindenEs}

Johannessen, Janne Bondi, Joel Priestley, Kristin Hagen, Tor A. Åfarli og Øystein Vangsnes. 2009. The Nordic Dialect Corpus - an advanced research tool. I: Proceedings of the 39th Nordic Conference of Computational Linguistics NODALIDA 2009, red. Kristina Jokinen og Eckhard Bick, 73-80. Tartu: Northern European Association for Language Technology (NEALT).

Kuryłowicz, Jerzy. 1965. The evolution of grammatical categories. Diogenes, 13(51): 55-71.

Lakoff, Robin. 1974. Remarks on this and that. Chicago Linguistic Society 10: $345-346$.

Lehmann, Christian. 2015. Thoughts on Grammaticalization. 3. utgave. Berlin: Language Science Press.

Levshina, Natalia. 2015 How to do linguistics with R: Data exploration and statistical analysis. Amsterdam/Philadelphia: John Benjamins.

Lie, Svein. 2008. Veldig sånn festejente. I: Språki Oslo: Ny forskning omkring talespråk, red. Janne Bondi Johannessen og Kristin Hagen, 7895. Oslo: Novus.

-2010. Bakgrunnsdeiksis og demonstrativer. I: Bo87. Festskrift till Bo Ralph, red. Erik Magnusson Petzell m. fl., 168-177. Meijerbergs institut för svensk etymologisk forskning, Göteborgs universitet.

Loureiro-Porto, Lucía. 2013. Morphological Productivity as a Trigger of the purfan/need replacement. I: Periphrasis, Replacement and Renewal: Studies in English Historical Linguistics, red. Irén Hegedűs og Dóra Pődör, 34-56. Newcastle upon Tyne: Cambridge Scholars Publishing.

Lundeby, Einar. 1965. Overbestemt substantiv i norsk og de andre nordiske språk. Oslo/Bergen/Tromsø: Universitetsforlaget.

Lødrup, Helge. 1982. De og dem i dialekten på Oslo vestkant. Norskrift, 37: $54-58$.

Miestamo, Matti. 2005. Standard negation: The negation of declarative verbal main clauses in a typological perspective. Berlin: Mouton de Gruyter.

Myklebust, Astrid. 2012. "Hva er de derre greiene der?": En syntaktisk analyse av komplekse demonstrativ i muntlig norsk. Upubl. mastergradsavhandling, Norges teknisk-naturvitenskapelige universitet.

Norsk ordbok: ordbok over det norske folkemålet og det nynorske skriftmålet. Bind 1 : A-doktriner. 1966. Oslo: Det norske samlaget. 
Reinhammar, Vidar. 1975. Pronomenstudier. Uppsala: Almqvist \& Wiksell.

$\mathrm{SAOB}=$ Ordbok över svenska språket. $1893-$ - URL: www.saob.se (lest mai 2020). Lund: Svenska Akademien.

Siemund, Peter. 2008. Pronominal gender in English: A study of English varieties from a cross-linguistic perspective. London: Routledge.

Stefanowitsch, Anatol og Stefan T. Gries. 2003. Collostructions: Investigating the Interaction of Words and Constructions. International Journal of Corpus Linguistics, 8(2), 209-243.

Stemshaug, Ola. 1968. Meldalsmålet. I: Meldal bygdebok, Bind 1. Bygdesoga til ikring 1700 : Frå åndsliv og kulturarbeid gjennom tida, red. Olaf Havdal, 395-442. Meldal: Meldal kommune.

Strahan, Tania E. 2008. Sjåpåhan mannen! On the definiteness and specificity of Scandinavian pronoun demonstratives. Nordic Journal of Linguistics, 31(2), 193-226.

Söderwall, Knut Fredrik. 1884-1918. Ordboköfver svenska medeltidsspråket. URL: https://spraakbanken.gu.se/en/resources/soederwall (lest august 2020). Stockholm: Svenska fornskriftsällskapet.

Trousdale, Graeme. 2014. On the relationship between grammaticalization and constructionalization. Folia Linguistica 48(2). 557-578.

Venås, Kjell. 2012. "Her sånn.” I: Fra holtijaR til holting: språkhistorie og språksosiologiske artikler til Arne Torp på 7o-årsdagen, red. Unn Røyneland og Hans-Olav Enger, 383-398. Oslo. Novus.

Vindenes, Urd. 2018a. Complex Demonstratives and Cyclic Change in Norwegian. Upubl. doktorgradsavhandling, Universitetet i Oslo.

-2018b. Cyclic renewal of demonstratives. Studies in Language, 42(3): 641-668.

Willis, David, Christopher Lucas og Anne Breitbarth. 2013. Comparing diachronies of negation. I: The development of negation in the languages of Europe: Volume I case studies, red. David Willis, Christopher Lucas \& Anne Breitbarth, 1-50. Oxford: Oxford University Press.

\section{Korpus}

BigBrother-korpuset. URL: http://www.tekstlab.uio.no/nota/bigbrother/ 


\section{URD VINDENES}

Diplomatarium Norvegicum. URL: http://www.dokpro.uio.no/dipl_ norv/diplom_felt.html.

KORP. URL: https://spraakbanken.gu.se/korp/

NDK = Nordisk dialektkorpus. URL: http://www.tekstlab.uio.no/ nota/scandiasyn/index.html

NoTa $=$ Norsk talespråksunders $\varnothing$ kelse (Oslo-delen). URL:

http://www. tekstlab.uio.no/nota/oslo/index.html

TAUS $=$ Talemålsunders $\varnothing$ kelsen i Oslo. URL:

http://www.tekstlab.uio. no/nota/taus/

\section{Abstract}

The aim of the study presented in this article is to give a corpus-based analysis of the functions of Norwegian demonstrative constructions that consist of a demonstrative, e.g. den 'that', denne 'this', bun 'she' and he 'han', and a reinforcer, typically her 'here' and der 'there'. In addition, the study aims to shed light on the development of demonstratives from the viewpoint of reinforcement cycles and paradigmatic competition. The data used in the analysis come from the Nordic Dialect Corpus and other speech corpora that consist of spontaneous speech data, as well as historical documents from the Diplomatarium Norvegicum. The article argues that since reinforcement of demonstratives can lead to the development of new demonstratives, this process may catalyze the grammaticalization of old ones through paradigmatic competition (niche competition). The analysis presented here sees reinforcement as a possible driving force behind grammaticalization, and not vice versa.

Urd Vindenes

Universitetet i Sørøst-Norge Institutt for språk og litteratur

Postboks 155 NO-3677 Notodden urd.vindenes@usn.no 


\section{Referat fra årsmøte i Bymålslaget torsdag 4. feb- ruar 2021}

Til stede digitalt på Zoom: Hans-Olav Enger, Kjersti Wictorsen Kola, Ragnhild Eik, Urd Vindenes og Andreas D. Haraldsrud.

Møtet begynte 18:oo og blei leda av Andreas D. Haraldsrud

Godkjenning av innkalling og dagsorden

Haraldsrud delte ut dagsorden. Innkalling og dagsorden blei godkjent.

\section{Årsrapport for 2020}

Haraldsrud leste opp og kommenterte årsrapporten, som blei godkjent.

\section{Regnskap for 2020}

Haraldsrud leste opp og kommenterte regnskapet. Økonomien i laget er stabil. Regnskapet blei godkjent.

\section{Rapport fra redaksjonen i Maal og Minne}

Redaktørene for de to numrene for 2020 har vært Hans-Olav Enger og Ingvil Brügger Budal. Tilgangen på stoff har vært god i 2O2O. Rapporten blei godkjent av årsm $\varnothing$ tet.

\section{Innkomne saker}

Det var ingen innkomne saker.

\section{Drøfting av virksomheten i tida framover}

Virksomheten dreier seg stort sett om Maal og Minne, og på nettsidene til Bymålslaget promoterer vi tidsskriftet. På sikt $\varnothing$ nsker vi å legge inn mer stoff på nettsidene. Det blei også nevnt at det er mulig å arrangere språkseminarer med midler og ressurser fra Bymålslaget, dersom noen $\varnothing$ nsker dette. 
REFERAT FRA ÅRSMØTE I BYMÅLSLAGET TORSDAG 4. FEBRUAR 2021

Valg

Haraldsrud la fram valgkomiteens forslag til styre for 2021. Årsmøtet godkjente forslaget enstemmig.

Leder: Andreas Drolsum Haraldsrud

Nestleder: Urd Vindenes

Kasserer: Andreas Drolsum Haraldsrud

Øvrig styre: Ragnhild Eik, Kjersti Wictorsen Kola og Anu Laanemets. Varamedlemmer: Ingen valgt.

Revisor: Botolv Helleland

Valgkomite: Styret

Møtet slutta klokka 18:30

Referent: Andreas Drolsum Haraldsrud 